\title{
Investigating Risk Disclosure Practices in the European Insurance Industry
}

\author{
Dirk Höring ${ }^{\mathrm{a}}$ and Helmut Gründl ${ }^{\mathrm{b}}$ \\ ${ }^{a}$ School of Business and Economics, Humboldt-Universität zu Berlin, Dr Wolfgang Schieren Chair for \\ Insurance and Risk Management, Spandauer Str. 1, 10999 Berlin, Germany. \\ ${ }^{b}$ Faculty of Economics and Business Administration, Chair of Insurance and Regulation, International \\ Center for Insurance Regulation, Goethe-Universität Frankfurt am Main, Grüneburgplatz 1, 60323 \\ Frankfurt am Main, Germany. \\ E-mail: gruendl@finance.uni-frankfurt.de
}

In light of the upcoming Solvency II Pillar 3 disclosure regulation for the insurance industry, this paper explores the risk disclosure practices in annual reports of European primary insurers in the Dow Jones Stoxx 600 Insurance Index between 2005 and 2009. On the basis of a self-constructed risk disclosure index, the study examines the relation between the extent of risk disclosure and insurance companies' characteristics such as size, risk, profitability, ownership dispersion, cross-listing, home country and type of insurance sold, to draw inferences regarding motives for enhanced risk disclosure based on positive accounting theory.

The Geneva Papers (2011) 36, 380-413. doi:10.1057/gpp.2011.13; published online 1 June 2011

Keywords: risk disclosure; insurance; Solvency II; content analysis; positive accounting theory

\section{Introduction}

At its most basic, the business model of insurers is to minimise the costs associated with pooling policy-holder risks. That this is indeed a risky business is amply demonstrated by the recent financial and economic crisis. With risk as its major resource and given the inherent opacity of the insurance business, ${ }^{1}$ it is only natural that insurance company stakeholders expect solid risk reporting from insurers especially in times of turmoil. ${ }^{2}$

Although multinational, multilisted insurance companies are subject to a plethora of disclosure requirements; anecdotal evidence from the media indicates that insurance companies became more silent with respect to their reporting activities during the crisis. ${ }^{3}$ Regulators and auditors alike argue that insurer risk reporting is insufficient,

\footnotetext{
${ }^{1}$ See Morgan (2002).

2 See Schanz (2009, p. 262).

${ }^{3}$ A recent press article in Handelsblatt (2010) describes that in Germany many insurers were more reluctant to provide transparency. The rating agency Fitch or the product testing agencies Franke \& Bornberg or Assekurata perceived higher rates of rating cancellations, less provision of product information and an increased number of publication bans.
} 
given the economic importance of the industry. The International Association of Insurance Supervisors (IAIS) ${ }^{4}$ notes that "most jurisdictions do not fully meet the [IAIS disclosure standards] requirements" and that only "in around 20 per cent of cases disclosure requirements exceed the IAIS minimum requirements". KPMG ${ }^{5}$ finds that "three insurance sector risk areas are on a mediocre level (insurance risk, investment risk, overall risk strategy), while the rest are on an inadequate level (asset liability management and liquidity risk, business risk, operational risk)". PricewaterhouseCoopers ${ }^{6}$ concludes that shareholder reporting "remains limited and more work may be required to meet demands for transparency and comparability". Hence, several current initiatives aim at improving insurer risk disclosure. For example, the European Commission emphasises disclosure requirements in the third pillar of the new Solvency II regulation, planned to be implemented in 2012. The objective of the disclosure requirements is to enable market participants to exercise market discipline so as to prevent excessive risk taking by the insurance industry. ${ }^{7}$ In addition, the International Accounting Standard Board is currently at work on improving the accounting procedures for insurance transactions in phase II of its project on insurance contracts.

This paper explores the risk disclosure practices in annual reports of European insurance companies in the Dow Jones Stoxx 600 Insurance Index during the period 2005-2009 and thus makes a substantial contribution to the relatively scarce literature on risk disclosure of financial institutions. Content analysis based on a selfconstructed risk disclosure index is employed to provide a comprehensive picture of the extent and development of European insurance companies' risk disclosure. This paper also empirically tests the relationships between the extent of risk disclosure and the sampled insurance companies' characteristics in an investigation of potential motives for enhanced risk disclosure based on positive accounting theory.

Our study reveals that in recent years the importance of risk disclosure increased substantially with regard to extent and location in the annual reports. Nevertheless, risk disclosures of the European insurance industry are still moderate on average, but with a strong dispersion among the sample insurers. The regression results show a significant positive relationship between the extent of risk disclosure and insurer size, which accords well with positive accounting theory and other empirical research. We find a significant positive relationship between risk disclosure and insurer risk and a significant negative relationship between risk disclosure and insurer profitability. We confirm the influence of cross-listing status and ownership dispersion on the extent of risk disclosure. Furthermore, we find evidence of inter-insurer and inter-country differences in risk disclosure practices.

The remainder of this paper is structured as follows. The next section locates the paper within the context of previous risk disclosure literature. The subsequent section describes the procedure used to measure the extent of risk disclosure in this paper.

\footnotetext{
${ }^{4}$ IAIS (2008, pp. 5-6).

${ }^{5}$ KPMG (2008, p. 14).

${ }^{6}$ PricewaterhouseCoopers (2008, p. 34).

${ }^{7}$ See Eling (2010, p. 1).
} 
Hypotheses regarding the relationship between the extent of risk disclosure and insurer characteristics are developed in the following section. The sample selection process and the research design are described in the section after that. The penultimate section provides and discusses the empirical results; the final section concludes.

\section{Literature review}

Schrand and Elliott ${ }^{8}$ and Solomon et al. ${ }^{9}$ call for more work aimed at enhancing the understanding of risk disclosure and empirical evidence suitable for testing theoretical frameworks. This call has not gone unheeded; there has been an increasing amount of work in this area. Most of the empirical work is focused on corporate risk disclosure. Linsley et al. ${ }^{10}$ point out that financial institution risk disclosure has received little academic attention and is almost exclusively focused on banks. Empirical studies on risk disclosure usually describe the extent, nature and development of risk disclosures, explore whether stakeholders find the risk information provided useful or investigate the factors that determine the level of risk disclosure.

The first strand of risk disclosure literature involves descriptive analysis of risk disclosures in the annual reports of financial institutions. Employing a content analysis approach on the annual reports of German insurers between 1999 and 2003, Kraft and Nolte ${ }^{11}$ conclude that although the quality of risk disclosure improved significantly during the time period studied, insight into the risk profile continues to be limited due to the lack of quantification and the absence of descriptions of prognosis assumptions. These results are in agreement with those of Sundmacher, ${ }^{12}$ who explores the operational risk disclosures of banks between 2004 and 2005. She adds that operational risk disclosure varies significantly across the analysed institutions and makes cross-sectional comparison by stakeholders difficult. Linsley and Shrives ${ }^{13}$ summarise the findings of the three Basel Committee studies on public disclosures by banks. They conclude that there is a general trend of banks disclosing more information, but that these institutions will need to improve their reporting significantly to comply with the upcoming third-pillar requirements of Basel II (which, at the time of their writing, was scheduled for the end of 2006).

Examples of the first strand of risk disclosure literature in the area of corporate risk reporting are the studies of Kajüter and Winkler, ${ }^{14}$ Lajili and Zéghal, ${ }^{15}$ and Linsley and Lawrence, ${ }^{16}$ who analyse risk disclosure in the annual reports of corporations in Germany, Canada and the United Kingdom, respectively, around the millennium change, and arrive at conclusions similar to studies with a focus on financial

\footnotetext{
${ }^{8}$ Schrand and Elliott (1998, p. 274).

${ }^{9}$ Solomon et al. (2000, p. 448).

${ }^{10}$ Linsley et al. (2006, p. 268).

${ }^{11}$ Kraft and Nolte (2005).

${ }^{12}$ Sundmacher (2006).

${ }^{13}$ Linsley and Shrives (2005a).

14 Kajüter and Winkler (2003).

15 Lajili and Zéghal (2005).

${ }^{16}$ Linsley and Lawrence (2007).
} 
institutions. Employing a content analysis approach, Kajüter and Winkler ${ }^{14}$ and Lajili and Zéghal ${ }^{15}$ conclude that although risk disclosure has improved, risk assessment and analysis is still quite limited and very general in nature. Linsley and Lawrence ${ }^{16}$ study the readability (or lack thereof) of risk disclosures, finding that risk disclosures are difficult or very difficult to read, but that there is no evidence that directors are deliberately concealing bad news.

A second strand of the literature on risk disclosure deals with the question of whether enhanced risk disclosure is beneficial to stakeholders. Baumann and Nier ${ }^{17}$ find that higher levels of risk disclosure are related to lower levels of stock return volatility. They conclude that a higher level of risk disclosure is useful to investors and may benefit the banks by decreasing their cost of capital and increasing the effectiveness of stock-based compensation. Nier and Baumann ${ }^{18}$ test the hypothesis that market discipline is effective in limiting bank default risk. Their regression analysis shows that an increase of their risk disclosure index from zero to unity results in an increase of the bank's capital ratios of approximately 6.5 per cent, leading to the conclusion that banks that disclose more risk information are subject to stronger market discipline and tend to hold relatively more capital. Hirtle ${ }^{19}$ and Pérignon and Smith ${ }^{20}$ investigate the market risk disclosures of banks. Using a value-at-risk (VaR) disclosure index, Hirtle ${ }^{19}$ finds that a greater extent of disclosure is associated with a subsequent lower risk profile and higher risk-adjusted returns. It seems that first movers in disclosure appear to have lower future returns, which the author interprets as possibly due to learning costs incurred by investors in assessing new risk information. Pérignon and Smith $^{20}$ investigate the development of VaR disclosure and the accuracy of the VaR figures. They conclude that although the level of VaR disclosures has increased, the quality of the VaR figures in predicting VaR exceedances and volatility of subsequent trading revenues shows no improvement during the period studied.

Examples of this strand of the literature on corporate risk disclosure include $\mathrm{Li}^{21}$ and Deumes, ${ }^{22}$ who analyse risk disclosure in annual reports and prospectuses to investigate whether these are associated with future earnings, shareholder returns and volatility of future stock prices. Dia and Zéghal ${ }^{23}$ transform qualitative descriptions of risk disclosures into quantitative numbers and test their association with traditional financial and accounting measures of risk and return.

A third and smaller strand of the risk disclosure literature focuses on the factors that influence the level of risk disclosure made by financial institutions. These studies investigate the relationship between the extent of risk disclosure and corporate characteristics such as size, risk and profitability. Linsley et al., ${ }^{10}$ in a sample of Canadian and U.K. banks, find that there is a positive relationship between the level of risk disclosure and bank size. Their results show no association between the level of

${ }^{17}$ Baumann and Nier (2004).

${ }^{18}$ Nier and Baumann (2006).

${ }^{19}$ Hirtle (2007).

${ }^{20}$ Pérignon and Smith (2008).

${ }^{21} \mathrm{Li}$ (2006).

${ }^{22}$ Deumes (2008).

${ }^{23}$ Dia and Zéghal (2008). 
risk disclosure and bank risk or profitability. Helbok and Wagner ${ }^{24}$ study the determinants of operational risk reporting by North American, European and Asian banks. Their results demonstrate a negative relationship between bank risk, measured by the leverage ratio, and bank profitability, measured by return on assets. Woods et $a l .{ }^{25}$ analyse the market risk disclosures of the world's top 25 banks. They are unable to support the hypothesis that the level of risk disclosure correlates with bank size. They also note that despite the shift towards accounting practice harmonisation, inter-country differences in disclosure practices remain.

In the third strand of literature, corporate risk reporting receives more attention. Researchers studied corporate risk reporting in developed countries, such as Italy, Japan, the United Kingdom, the Netherlands and Belgium, as well as corporate risk reporting in developing countries such as Malaysia and the United Arab Emirates. ${ }^{26}$ The most consistently confirmed finding is the size effect, that is, the positive relationship between the level of risk disclosure and firm size.

This paper's focus on the insurance industry makes it a unique contribution to the third strand of risk disclosure literature. To our knowledge, the factors that influence risk disclosure in this particular industry have not been studied to date. The study closest in spirit to ours is Adams and Hossain, ${ }^{27}$ who studied the public disclosure of life insurance companies in New Zealand between 1988 and 1993. Although their focus is on voluntary disclosure, their results indicate that public listing, size, product diversity, amount of reinsurance, number of non-executive directors and distribution system are positively related to the level of disclosure.

\section{Risk disclosure measurement}

The method used in this paper is content analysis. Krippendorff ${ }^{28}$ defines content analysis as a research technique for making replicable and valid inferences from texts to the contexts in which they are used. This technique can involve several different procedures for measuring the extent of disclosure in narratives. Beattie et al. ${ }^{29}$ define three of these procedures as subjective analyst ratings, semi-objective textual analysis (thematic content analysis, readability studies, linguistic analysis), and semi-objective disclosure indices, while the latter is the procedure of choice for our study.

A disclosure index is an ex-ante specified list of items. In this procedure, narratives and non-narratives are scrutinised for the presence of these items and scores are awarded based on their presence. ${ }^{30}$ Disclosure indices share some of the problems

\footnotetext{
${ }^{24}$ Helbok and Wagner (2006).

${ }^{25}$ Woods et al. (2008).

${ }^{26}$ Studies of developed countries include Beretta and Bozzolan (2004), Ali (2005), Linsley and Shrives (2005b, 2006), Abraham and Cox (2007), Konishi and Ali (2007), Deumes and Knechel (2008) and Vandemaele et al. (2009). See Amran et al. (2009) and Hassan (2009) for risk disclosure studies in developing countries.

${ }^{27}$ Adams and Hossain (1998).

${ }^{28}$ Krippendorff (2004, p. 18).

${ }^{29}$ Beattie et al. (2004, p. 209).

${ }^{30}$ See Beattie et al. (2004, p. 208).
} 
inherent to textual analysis, such as being limited to publicly available documents excluding, for example, analyst calls and conferences. The procedure is criticised for the subjectivity involved in constructing the index and conducting the scoring. ${ }^{31}$ Hence, it is important that the results of disclosure index studies be reliable and valid, can be replicated by other researchers and actually measure what the researcher intended to measure. ${ }^{32}$ Several risk disclosure studies make use of a disclosure index, ${ }^{33}$ and it is our method of choice in this paper as well.

There is no risk disclosure index readily available that meets the needs of our study. Kraft and Nolte ${ }^{34}$ make use of an insurance-specific risk disclosure index that is based on the German Accounting Standards (GAS 5-20) for German insurers. We decided against using this index because it fails to cover all insurer risks, such as liquidity and operational risk. Furthermore, the index is based on accounting requirements that are valid only for German insurers not obliged to prepare a consolidated annual report in accordance with the German Commercial Code. $\mathrm{KPMG}^{5}$ use a risk disclosure index to survey risk disclosure for 14 insurance companies in Europe. The disclosure index consists of six subindices (insurance risk, investment risk, asset liability management and liquidity risk, business risk, operational risk, overall risk strategy and shareholder value) and grades on a scale from zero to five. However, this risk disclosure index is proprietary and thus unavailable for our study. Since our sample consists of European insurers reporting under IFRS and we want to provide a holistic picture of all risks, we decided to create a new index.

Our self-constructed disclosure index is mainly based on the Chief Risk Officer (CRO) Forum proposal for public risk disclosure. ${ }^{35}$ Other regulatory documents were used to supplement the CRO Forum proposal, such as IAIS, ${ }^{36}$ Joint Forum $^{37}$ and Committee of European Insurance and Occupational Pensions Supervisors (CEIOPS). ${ }^{38}$ Hence, the risk disclosure index takes the perspective of a skilled rating expert or equity analyst who thoroughly studies the insurer's annual report to investigate the insurance companies' risk profile. The CRO Forum comprises the chief risk officers of global insurance companies. Hence, we expect its proposal for public risk disclosure and our risk disclosure index to reflect the current state-of-the-art risk disclosure requirements deemed appropriate for our sample of the largest publicly listed insurers in Europe. The index contains currently mandatory disclosure, potentially mandatory disclosure under the Solvency II Pillar 3 regime and voluntary disclosure. Hence, insurers that exceed the current regulatory disclosure requirements receive higher risk disclosure scores due to the potentially mandatory and voluntary disclosure they provide. We do not distinguish between these types of disclosures for

\footnotetext{
${ }^{31}$ See Marston and Shrives (1991, p. 207).

32 See Marston and Shrives (1991, pp. 197-198).

${ }^{33}$ Risk disclosure studies making use of a disclosure index include Hassan (2009), Woods et al. (2008) and Pérignon and Smith (2008).

${ }^{34}$ Kraft and Nolte (2005, p. 432).

${ }^{35}$ CRO Forum (2008).

${ }^{36}$ IAIS $(2002,2004,2005,2006)$.

37 Joint Forum (2004).

${ }^{38}$ CEIOPS (2009).
} 
several reasons. First, although a pure measure of voluntary risk disclosure introduces less noise into the analysis of managerial incentives to report, Ahmed and Courtis ${ }^{39}$ find that differences in the results from voluntary, mandatory and aggregate disclosure indices are not explained by index construction. Second, even in the case of mandatory disclosure, insurers have substantial discretion in the informativeness of the disclosures and the detail provided. ${ }^{40}$

The index consists of seven subindices by risk category and a total of 45 single items that are shown in Table 1.

The disclosure index focuses on disclosure of an insurer's risk profile. Hence, it excludes items from the insurer's risk report section that have to do with the risk governance framework and the capital and risk management processes. The items in the disclosure index are limited to information that all sample companies could disclose, thus avoiding the problem that certain items will not be applicable for a particular company. ${ }^{41}$ To make the disclosure scores for pure non-life, pure life and composite insurers comparable, the subindex for underwriting risk is an aggregation of the scores for non-life underwriting risk items and life underwriting risk items. We applied a Solvency I required capital proxy, based on premiums or reserves, to weigh the underwriting risk items so as to avoid a bias towards the life risk disclosure for composite insurers. ${ }^{42}$

Similar to Botosan, ${ }^{43}$ Robb et al. ${ }^{44}$ and Kraft and Nolte, ${ }^{11}$ the items of the risk disclosure index have an ordinal coding scheme with three levels to allow the assessment of disclosure "quality". Binary or three-level ordinal coding schemes are frequently used in content analysis. ${ }^{45}$ According to ex-ante specified rules, the analysis differentiated for each item between no disclosure $($ score $=0$ ), basic disclosure (score $=1)$ and extensive disclosure $($ score $=2)$. For example, insurers who do not disclose a VaR figure for their market risk exposure received a score of 0 . Insurers that additionally provided information on VaR for market risk subrisks, such as equity price risk and interest rate risk, explained the split of VaR for their operating segments, or provided supporting market VaR at different confidence intervals received a score of 2 . Multiple references to the same item were counted only once; quantitative information, a higher level of detail and/or enhanced presentation formats scored higher.

Each item in the risk disclosure index received equal weighting in the total risk disclosure index score by determining the weight for each of the seven subindices

\footnotetext{
${ }^{39}$ Ahmed and Courtis (1999, p. 54).

${ }^{40}$ For example, to comply with IFRS 7 (40), it is sufficient to provide a sensitivity analysis for each type of market risk. However, managers may also comply by providing value-at-risk measures.

${ }^{41}$ See Marston and Shrives (1991, p. 204).

${ }^{42}$ We weighted the non-life and life underwriting risk scores with a Solvency I required capital proxy. The non-life weight was determined by 16 per cent of non-life gross premiums written. The life weight was determined by the sum of 4 per cent of gross traditional life reserves and 1 per cent of gross unit-linked reserves.

${ }^{43}$ Botosan (1997).

${ }^{44}$ Robb et al. (2001).

${ }^{45}$ See Beattie et al. (2004, p. 210).
} 


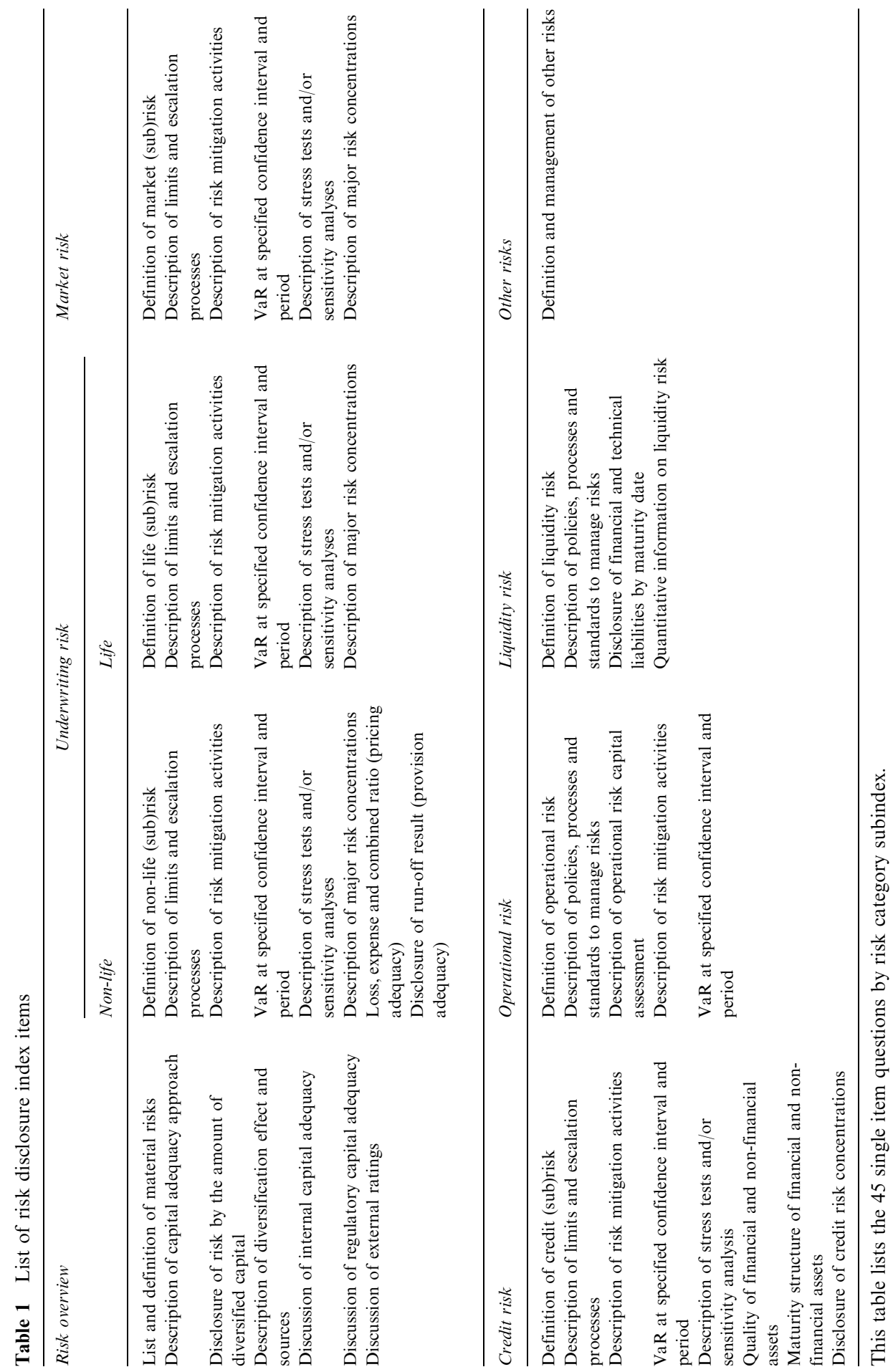


according to the number of subindex items. ${ }^{46}$ Although this implicitly assumes that each item is equally important, it does eliminate the subjectivity inherent to determining item weights and, given a sufficiently large number of items, disclosure scores tend to yield the same statistical results. ${ }^{47}$ Hence, unweighted disclosure indices are often used in the existant literature. ${ }^{48}$ Finally, the total risk disclosure scores were normalised to maximum risk disclosure and full scoring in all items $(D S c o r e=100)$ and no risk disclosure or zero scoring in all items (DScore $=0)$.

In evaluating the results of a disclosure index, Marston and Shrives ${ }^{49}$ stress the importance of validity and reliability. The disclosure index scores are deemed valid if they measure what the researcher intended to measure, and are judged to be reliable if they can be replicated by other researchers.

To show the validity of our disclosure index results, we investigated the correlations between our scores and two other measures of disclosure: number of press articles and analyst following (see Botosan ${ }^{43}$ for similar tests). We expect that our disclosure scores will be positively correlated with the number of Financial Times articles having the insurer's name in the headline for each year. Building on the findings of Lang and Lundholm ${ }^{50}$ that firms with more informative disclosure policies have a larger analyst following due to an information cost reduction and an increase in analyst supply, we expect the number of analyst reports in Bloomberg to be positively correlated with the disclosure scores. Our analysis shows that all correlation coefficients are significantly positive on a 1 per cent level or better.

A disclosure index analysis is deemed reliable if it results in the same scores independent of the circumstances of its implementation. ${ }^{51}$ We test the reliability of our coding procedure by performing a multicoder analysis and measuring the degree of agreement achieved among coders using Krippendorff's agreement coefficient alpha $(\alpha)$. The coding was done by one of the authors using an ex-ante specified item checklist and specific examples illustrating the decision rules for point scoring. The author scored scoring an initial sample of 40 annual reports. Then, two independent coders, after instruction and training, coded 10 per cent of this initial sample. Percentage pair-wise agreement ranged from 82 to 86 per cent and Krippendorff's $\alpha$, which basically corrects for agreement achieved by chance, was calculated at 76 per cent. There is no standard test of significance for this statistic, but as a general rule, Krippendorff ${ }^{52}$ advises relying only on data that has an $\alpha=80$ per cent or higher, or an

${ }^{46}$ The aggregated underwriting risk subindex received a weight according to the average number of non-life underwriting risk and life underwriting risk items.

${ }^{47}$ See Helbok and Wagner (2006) and Marston and Shrives (1991, p. 203). We test the robustness of our regression results by applying two other weighting schemes: equal weightings for each subindex and a risk-capital-based weighting based on insurers' regulatory capital requirements from the CEIOPS (2008) Quantitative Impact Study 4. The results of both regressions are comparable to those reported here.

${ }^{48}$ See Lopes and Rodrigues (2007, p. 36). Unweighted disclosure index studies include Woods et al. (2008), Deumes and Knechel (2008) and Pérignon and Smith (2008).

${ }^{49}$ Marston and Shrives (1991, pp. 197-198).

${ }^{50}$ Lang and Lundholm (1996).

${ }^{51}$ See Krippendorff (2004, p. 211).

${ }^{52}$ Krippendorff (2004, p. 241). 
$\alpha=67$ per cent if the data is to be used in exploratory research. All coding discrepancies were jointly resolved and adjustments to the decision rules made if necessary.

\section{Hypothesis development}

This paper analyses several firm characteristics that influence the level of risk disclosure in the European insurance industry. The "contemporaneous" positive accounting theory of Watts and Zimmerman ${ }^{53}$ provides the theoretical framework for our hypothesis development. According to this theory, managerial discretion over disclosure and accounting choices is exercised to minimise contracting costs (or, put another way, to maximise firm value) and to redistribute these costs opportunistically (or, to maximise managers' private utility). Contracting costs are defined to include transaction costs, agency costs (e.g., monitoring costs), information costs, renegotiation costs and bankruptcy costs. They are incurred in market transactions, transactions internal to the firm and in political process-related transactions, such as avoiding stricter regulation. We test for empirical relationships between the extent of risk disclosure and insurer size, risk and profitability. As further control variables we consider a number of insurer characteristics, such as ownership dispersion, crosslisting, home country, additional banking activities and type of insurance operations. Audit firm size and industry classification, often used as control variables in other studies, are not used as such here since all companies in the sample are audited exclusively by the "Big Four" auditors (PricewaterhouseCoopers, KPMG, Ernst \& Young, Deloitte) and all of them operate within the same industry.

\section{Size}

Positive accounting theory predicts a positive relationship between insurer size and the extent of risk disclosure. Larger insurers have larger fractions of outside equity and debt capital to total assets and hence are subject to higher agency costs since monitoring becomes more complex and expensive. ${ }^{54}$ To reduce the associated contracting costs and enhance investor, as well as policy-holder, confidence, bigger insurers are likely to disclose more risk information. Moreover, size is a proxy for public, regulatory and political attention. ${ }^{55}$ Insurers will attempt to counter the associated higher political costs with enhanced risk disclosure. Other arguments related to insurer size involve decreasing proprietary costs related to disclosure of competitive information, possession of advanced data-gathering and reporting systems and processes, and increasing ability to attract and hire highly skilled individuals. ${ }^{56}$

Firm size, measured as market capitalisation, total assets, revenues, or number of shareholders or employees, is the most often empirically tested variable in disclosure

\footnotetext{
${ }^{53}$ Watts and Zimmerman (1990).

54 See Jensen and Meckling (1976, p. 348).

${ }^{55}$ Watts and Zimmerman (1990, p. 139).

${ }^{56}$ See Lopes and Rodrigues (2007, p. 32), Ahmed and Courtis (1999, p. 530) and Beretta and Bozzolan (2004, p. 281).
} 
studies. Most disclosure studies find a significant positive relationship between the extent of disclosure and firm size ${ }^{57}$ hence, the following hypothesis:

H1: Ceteris paribus, there is a positive relationship between insurer size measured by market capitalisation and the extent of risk disclosure.

Risk

Positive accounting theory predicts a positive relationship between the level of risk and the extent of risk disclosure. Agency and bankruptcy costs are an increasing function of the shareholder's residual risk, proxied for example by the leverage ratio. ${ }^{58}$ If there is substantial information asymmetry between management and other stakeholders, contracting costs increase because stakeholders expect that managers of companies with a high level of risk will avoid disclosure and take advantage as much as possible of their discretion as to reporting choices. To reduce the contracting costs associated with higher levels of risk and greater information asymmetry and maximise firm value, companies will increase risk disclosure. On the basis of the political cost argument, Helbok and Wagner ${ }^{24}$ conclude that banks with a high level of debt increase disclosure in an attempt to ward off regulatory attention. In general, public pressure on management to provide a description and explanation of risks increases as knowledge of the company's risk level becomes more widely known. ${ }^{59}$

Several measures of risk are applied in disclosure studies: one of the most popular, especially for corporate disclosure studies, being the leverage ratio. Many studies test other measures of risk, such as product and regional diversification, stock volatility, book-to-market ratio, market beta and other risk scores, but the empirical results for the relationship between risk and the extent of disclosure are ambiguous. ${ }^{60}$ On the basis of positive accounting theory, we hypothesise:

H2: Ceteris paribus, there is a positive relationship between insurer level of risk measured by book-to-market ratio and extent of risk disclosure.

\section{Profitability}

Profitability is perceived as a proxy for the company's ability to generate capital and restore equity. Thus, poor profitability increases the perceived risk level of the

\footnotetext{
${ }^{57}$ Studies that find a significant positive relationship between the extent of risk disclosure and size include Amran et al. (2009), Deumes and Knechel (2008), Konishi and Ali (2007), Linsley et al. (2006) and Ali (2005). Beretta and Bozzolan (2004, 2008) find no significant relationship between their constructed measures of disclosure quality and firm size. Likewise, Woods et al. (2008) do not find market capitalisation to be a significant explanatory variable.

58 See Jensen and Meckling (1976, p. 345).

${ }^{59}$ See Linsley and Shrives (2006, p. 391).

${ }^{60}$ Studies that find a positive relationship between leverage and risk disclosure include Helbok and Wagner (2006), Deumes and Knechel (2008) and Hassan (2009). However, many studies reject a positive relationship, including Ali (2005), Linsley and Shrives (2005b, 2006), Abraham and Cox (2007), Konishi and Ali (2007) and Amran et al. (2009).
} 
company by the market and increases public pressure on the insurer to provide more risk information. ${ }^{61}$ If there is substantial information asymmetry between management and other stakeholders, contracting costs will increase because stakeholders will expect that managers will disclose less risk information in an effort to improve perceptions of their risk-adjusted performance. ${ }^{62}$ Similar to high levels of risk, poor performance will increase the contracting costs of the company. To reduce these costs company will tend to enhance their risk reporting.

Empirical evidence on the relationship between profitability and the extent of risk disclosure is mixed. The majority of studies find no significant relationship between profitability, measured by return on equity, return on assets, dividend payout or shareholder returns, and risk disclosure. ${ }^{63}$ On the basis of the theoretical arguments, we develop the following hypothesis:

H3: Ceteris paribus, there is a negative relationship between insurer profitability measured by the return on equity and the extent of risk disclosure.

\section{Ownership dispersion}

Concentration of ownership is associated with extent of disclosure. Higher levels of outside equity ownership are accompanied by higher agency costs. ${ }^{64}$ Public, regulatory and political scrutiny of the insurer will increase with broader outside ownership and dependence on small shareholders for refinancing with larger free float. Likewise, if fewer shareholders control the insurer, information will be shared internally rather than through public disclosure. ${ }^{65}$ Management will try to reduce those agency and political costs by issuing more risk information. Barako et al. ${ }^{66}$ as well as Deumes and Knechel $^{67}$ find a significant negative relationship between ownership concentration and disclosure. Likewise, Konishi and $\mathrm{Ali}^{68}$ see a negative relationship between the concentration of the top ten shareholdings and disclosure, although it is not significant. Hence, we develop the following hypothesis:

H4: Ceteris paribus, there is a positive relationship between insurer ownership dispersion measured by free float and extent of risk disclosure.

\footnotetext{
${ }^{61}$ See Helbok and Wagner (2006), Vandemaele et al. (2009).

${ }^{62}$ See Ahmed and Courtis (1999, p. 38), Linsley et al. (2006, p. 274).

${ }^{63}$ Studies that find no relationship between profitability and disclosure include Ahmed and Courtis (1999), Ali (2005), Barako et al. (2006), Linsley et al. (2006), Konishi and Ali (2007), Beretta and Bozzolan (2008) and Hassan (2009). Deumes and Knechel (2008) find a significant positive relationship of return on assets and risk disclosure of corporations in the Netherlands, whereas Helbok and Wagner (2006) find a significant negative relationship between return on equity and operational risk disclosure for international banks. Likewise, Vandemaele et al.'s (2009) results show a significant negative relationship between return on assets and risk disclosure of corporations in Belgium.

${ }^{64}$ See Jensen and Meckling (1976, p. 345).

${ }^{65}$ See Ali (2005, p. 119).

66 Barako et al. (2006).

${ }^{67}$ Deumes and Knechel (2008).

${ }^{68}$ Konishi and Ali (2007).
} 
392

\section{Cross-listing}

Cross-listings are generally associated with higher agency costs. Foreign investors are unfamiliar with national accounting, regulatory and market practices, ${ }^{69}$ giving management an incentive to increase disclosure to reduce contracting costs. Moreover, foreign listings require other or more regulatory-driven disclosure, and good corporate governance, along with no additional transaction costs, argue for disclosure in all markets. ${ }^{70}$ This argument holds especially for listings in the United States since the Sarbanes-Oxley Act of 2002 went into effect. The empirical evidence on listing and cross-listing in the United States indicates a positive relationship with the extent of disclosure. ${ }^{71}$ Hence, we hypothesise the following:

H5: Ceteris paribus, there is a positive relationship between extent of risk disclosure and cross-listing in the United States.

\section{Home country}

Different legal and institutional settings, not to mention cultural differences in accounting, regulatory and market practices, may result in different degrees of voluntary disclosure. ${ }^{72}$ One of the theoretical powerhorses on the impact of cultural values on disclosure is Gray. ${ }^{73}$ On the basis of Hofstede's ${ }^{74}$ work on culture, Gray ${ }^{73}$ links societal values and institutional norms with accounting values and systems to develop a theory on the cultural influence on accounting systems and financial disclosure. The theory of Gray $^{73}$ was the focus of extensive empirical research. ${ }^{75}$ Specific disclosure studies that investigate cross-country differences in disclosure levels include Robb et al., ${ }^{44}$ Vanstraelen et al. ${ }^{76}$ and Woods et al. ${ }^{25}$ Woods et al. ${ }^{25}$ investigate the market risk disclosure of international banks between 2000 and 2006. Their analysis shows that Mediterranean countries (Italy, Spain and France) have lower levels of market risk disclosure. Hence, our next hypothesis:

H6: Ceteris paribus, the level of insurer risk disclosure depends on cultural differences of their home countries.

\section{Banking activities and type of insurance}

We control for the type of business operations conducted by the insurers in our sample. We differentiate between bancassurance providers and insurers without

\footnotetext{
${ }^{69}$ See Lopes and Rodrigues (2007, p. 33).

${ }^{70}$ See Ahmed and Courtis (1999, p. 540) and Abraham and Cox (2007, p. 234).

${ }^{71}$ Ahmed and Courtis (1999), Robb et al. (2001), Abraham and Cox (2007), Lopes and Rodrigues (2007) and Deumes and Knechel (2008) show a positive relationship between listing status and disclosure.

${ }^{72}$ See Vanstraelen et al. (2003) and Woods et al. (2008).

73 Gray (1988).

${ }^{74}$ Hofstede's (1980).

${ }^{75}$ See Finch (2010).

${ }^{76}$ Vanstraelen et al. (2003).
} 
banking and asset management operations, and between the extent of non-life and life business of the insurer.

Insurers engaged in bancassurance activity come under the currently more sophisticated Basel II regulation and disclosure requirements for their banking and asset management operations. ${ }^{77}$ This situation may change in light of the ongoing Solvency II and IFRS 4 initiatives. Owing to their more stringent regulatory disclosure requirements, insurers conducting banking operations will likely have a higher degree of risk disclosure. We thus hypothesise:

H7: There is a positive relationship between significant bancassurance operations and the extent of risk disclosure.

Finally, we control for the extent of non-life vs. life business of an insurer. Compared to non-life business, life business is longer term in nature and inherently more complex. ${ }^{78}$ We expect the agency and information costs of life insurance operations to be higher than those of non-life. Moreover, due to their importance in the public's retirement provisioning, life insurers are the subject of a great deal of public and political attention. According to positive accounting theory, both these circumstances imply that life insurers will tend to provide more information regarding their risk profile so as to reduce contracting costs. However, the complexity of the life business requires more expensive and sophisticated risk management and reporting systems. Moreover, risk information in the life insurance business is proprietary. For example, detailed market risk information for life business may reveal the insurer's investment strategy. The cost of providing risk information on the life business may thus outweigh the benefit of reduced contracting costs. Hence, we hypothesise the following:

H8: There is no relationship between the level of life operations measured by the regulatory capital requirements and the extent of risk disclosure.

\section{Sample selection and research design}

The initial sample consists of all the insurers included in the Dow Jones Stoxx 600 Insurance Index for Europe as of September 2009. The Dow Jones Stoxx 600 Insurance Index for Europe comprises the 37 largest European insurers as measured by free float market capitalisation. Our goal is to cover the majority of the European insurance market, and the companies in the Dow Jones Stoxx 600 Insurance Index provide insurance for approximately 50 per cent of the market, making them quite representative of the universe we wish to investigate. ${ }^{79} \mathrm{We}$ exclude reinsurers

\footnotetext{
${ }^{77}$ See KPMG (2008, p. 8).

${ }^{78}$ See De Mey (2009, p. 229).

79 According to the Boston Consulting Group (2008, p. 7), the European insurance market has an insurance premium volume of approximately EUR 1,000 billion. The volume of gross premiums written by our initial sample of insurers in 2008 is over EUR 600 billion or approximately 60 per cent of the European insurance market. The final sample excludes mainly reinsurers, and has a volume of gross premiums written in 2008 of over EUR 546 billion or a market share of approximately 55 per cent (Table 2).
} 
because their business model is completely different from that of primary insurers. We do not include large mutual insurance companies for several reasons. Since we are already dealing with cross-country variation in legal and institutional settings, we want to use the harmonisation provided by international accounting standards and stock exchange regimes. Moreover, to test the relationship of insurer risk and the extent of risk disclosure, we rely on a market measure (book-to-market ratio) to avoid the problems inherent in using the traditional leverage ratio to measure the level of risk for financial institutions. Table 2 provides a list of the insurers included in our sample. Table 3 describes the regional distribution of insurers and gross premiums.

The sample time horizon covers the financial years 2005-2009, each of which is equivalent to the calendar year for all the insurers in our sample. The period after 1 January 2005 was chosen since after that date all publicly listed companies in the European Union have to prepare their consolidated annual reports in accordance with the IFRS, making the annual reports more comparable.

During the sample horizon IFRS 7 (Financial Instruments: Disclosures) was introduced. IFRS 7 consolidated and expanded disclosure requirements on financial instruments. Specifically, insurance companies had to provide quantitative and qualitative market risk disclosures for annual periods beginning on or after 1 January 2007. To substantiate our results, we split the sample into two subsamples and performed regression analysis on the subsamples including annual reports before and after the introduction of IFRS 7 in 2007.

For the content analysis, the European version of the whole group annual report and - if available - a separate European embedded value report is used. Other documents, such as annual reports written for other jurisdictions, the Form 20-F, investor and analyst presentations, or press clippings, are not analysed. The annual report is the most important instrument of shareholder communication and is a good proxy for the firm's disclosure policy. ${ }^{80}$ The content analysis is not focused on particular sections of the annual report, such as the narrative management commentary preceding the financial statements, but covers the entire annual report since risk information is widely scattered throughout these reports. $^{81}$

The final sample is smaller by 18 per cent than the initial sample of 37 insurers listed on the Dow Jones Stoxx 600 Insurance Index for the years 2005-2009 (original sample: 185 insurer-year observations; final sample: 152 insurer-year observations). The company Jardine Lloyd Thompson is omitted since the nature of its business is pure insurance brokerage ( -5 insurer-year observations). Five reinsurers (Munich $\mathrm{Re}$, Swiss Re, SCOR, Amlin and Hannover Re) are due to their business model being so different from that of primary insurance ( -25 insurer-year observations). Standard Life plc is excluded from the analysis for the year 2005 since the company was demutualised and publicly listed in 2006 ( -1 insurer-year observation). Finally, the 2009 annual reports of Alleanza Assicurazioni S.p.A. and Friends Provident plc

\footnotetext{
${ }^{80}$ See Botosan (1997, p. 326) and Beretta and Bozzolan (2004, p. 276).

${ }^{81}$ See Woods et al. (2008, p. 15).
} 
Table 2 List of sample insurers

\begin{tabular}{|c|c|c|c|}
\hline No. & Insurer & Home country & $\begin{array}{c}\text { Gross premiums } \\
\text { (EUR billion) }\end{array}$ \\
\hline 1 & Allianz & Germany & 66.2 \\
\hline 2 & AXA & France & 84.7 \\
\hline 3 & ING & Netherlands & 43.8 \\
\hline 4 & Zurich Financial Services & Switzerland & 38.1 \\
\hline 5 & Generali & Italy & 68.8 \\
\hline 6 & Prudential & United Kingdom & 26.9 \\
\hline 7 & Aviva & United Kingdom & 51.4 \\
\hline 8 & Aegon & Netherlands & 22.4 \\
\hline 9 & Sampo & Finland & 4.6 \\
\hline 10 & Fortis & Netherlands & 8.5 \\
\hline 11 & Old Mutual & United Kingdom & 7.3 \\
\hline 12 & Standard Life & United Kingdom & 5.1 \\
\hline 13 & Legal \& General & United Kingdom & 8.4 \\
\hline 14 & RSA & United Kingdom & 10.3 \\
\hline 15 & Bâloise & Switzerland & 4.5 \\
\hline 16 & Alleanza Assicurazioni & Italy & 3.7 \\
\hline 17 & Admiral & United Kingdom & 0.5 \\
\hline 18 & CNP Assurances & France & 28.3 \\
\hline 19 & Friends Provident & United Kingdom & 1.4 \\
\hline 20 & Swiss Life & Switzerland & 9.3 \\
\hline 21 & Mapfre & Spain & 14.3 \\
\hline 22 & Irish Life \& Permanent & Ireland & 0.7 \\
\hline 23 & Vienna Insurance & Austria & 7.9 \\
\hline 24 & Storebrand & Sweden & 3.5 \\
\hline 25 & TrygVesta & Denmark & 2.2 \\
\hline 26 & Topdanmark & Denmark & 1.7 \\
\hline 27 & Catlin & United Kingdom & 1.9 \\
\hline 28 & Helvetia & Switzerland & 3.5 \\
\hline 29 & Cattolica Assicurazioni & Italy & 3.0 \\
\hline 30 & Fondiaria-SAI & Italy & 11.2 \\
\hline \multirow[t]{2}{*}{31} & Brit Insurance & United Kingdom & 1.6 \\
\hline & & Total & 545.7 \\
\hline
\end{tabular}

This table lists the insurers included in the final sample based upon the Dow Jones 600 Insurance Index. It excludes the following insurers from the Dow Jones 600 Insurance Index: Jardine Lloyd Thompson, Munich Re, Swiss Re, SCOR, Amlin and Hannover Re. Home country is the country of incorporation. Gross premiums (EUR billion) are the gross premiums written for the financial year 2008 using EUR exchange rates as of 1 January 2005. If gross premiums written are not available from the annual report gross premiums earned or net premiums earned are used.

are not available due to mergers ( -2 insurer-year observations). Our data set is unavoidably affected by a survivorship bias. It excludes annual reports of insurers that exited the Dow Jones Stoxx 600 Insurance Index in the period 2005-2009 due to takeover, insolvency or failure to meet the index criteria.

The final sample consists of 152 insurer-year observations for 31 insurers. Our study covers six non-life insurers, 16 life insurers and nine composite insurers. Of the 
Table 3 Descriptive data on European countries covered

\begin{tabular}{llrr}
\hline Region & Home country & Number of insurers & Gross premiums (EUR billion) \\
\hline Region1 & Austria & 1 & 7.9 \\
(Germanic) & Germany & 1 & 66.2 \\
& Switzerland & 4 & 55.4 \\
& Total & 6 & 129.5 \\
& & & \\
Region2 & Ireland & 1 & 0.7 \\
(Anglo) & United Kingdom & 10 & 114.8 \\
& Total & 11 & 115.5 \\
Region3 & & & 74.7 \\
(Nordic) & Netherlands & 3 & 3.9 \\
& Denmark & 2 & 4.6 \\
& Finland & 1 & 3.5 \\
& Sweden & 1 & 86.7 \\
Region4 & Total & 7 & 113.0 \\
(More developed Latin) & Italy & & 86.7 \\
& Spain & 2 & 14.3 \\
& Total & 4 & 214.0 \\
\hline
\end{tabular}

This table reports the number of insurers and total gross premiums by country and regional clustering used for the regression analysis. Home country is the country of incorporation. Number of insurers is the number of insurers incorporated in the specified country. Gross premiums (EUR billion) are the total gross premiums written by the insurer for the financial year 2008 independent of the source country where the insurance policies are sold using EUR exchange rates as of 1 January 2005. If gross premiums written are not available from the annual report gross premiums earned or net premiums earned are used.

31 insurers, six were engaged in significant banking operations during the sample period (bancassurance). ${ }^{82}$

To test our hypotheses, variables for the extent of risk disclosure, size, risk, profitability and the other control factors need to be measured. The extent of risk disclosure is measured by the risk disclosure scores (DScore) of our self-constructed risk disclosure index. To be able to compare dependent variables in our multicountry and multicurrency setting, we converted all nominal amounts to euros, ${ }^{83}$ using a constant exchange rate as of 1 January 2005. When measuring the size of financial institutions, typically either total assets or market capitalisation is used but there is no theoretical reason to favour one measure over the other. ${ }^{84} \mathrm{We}$ employ year-end market capitalisation (MCap) as a measure of insurer size, but year-end total assets yield comparable results. We use year-end book-to-market ratio $(B t M)$ to measure insurer

${ }^{82}$ We classified an insurer as a reinsurer if reinsurance reserves exceeded 25 per cent of total insurance reserves. Composite insurers are defined as primary insurers where the required capital for the non-life business is between 25 per cent and 75 per cent of the total required capital according to our Solvency I regulatory capital proxy. We classified insurers as insurers with bancassurance activity if the ratio of asset management and banking assets to total assets exceeded 25 per cent.

${ }^{83}$ Financial figures in the annual reports were denominated in USD, GBP, CHF, NOK, and DKK.

${ }^{84}$ See Linsley et al. (2006, pp. 274-275). 
risk. Similar to Linsley et al. ${ }^{85}$ we refrain from using the traditional leverage ratio. Leverage is heavily dependent on the type of insurance activity conducted and is significantly different for insurers in the life business compared to those in the non-life business that are both included in our sample. Moreover, leverage may be an insufficient measure of insurers' risk. As a measure of relative profitability, disclosure studies typically employ either return on assets or return on equity. We use return on equity $(R o E)$, which is a prominent key performance indicator reported by insurers. We calculate the return on equity as the ratio of net profit attributable to shareholders before discontinued operations and the year-average book value of shareholders' equity. Comparable results are reached when using return on assets as a proxy for profitability, however. As a measure of ownership dispersion, we use percentage free float (Float) since all our sample insurers are listed. The measure of free float is a proxy for the degree to which an insurer is owned by many shareholders in small parcels. We measure crosslisting in the United States as binary variable (USList), which identifies insurers with foreign listing on a U.S. stock exchange. In addition, we define three dummy variables (Region1, Region2 and Region3) to control for region of incorporation. Hofstede ${ }^{74}$ identified cultural areas based upon four value dimensions, using cluster analysis, and taking into account geographical and historical factors. For our analysis we adopted four regional clusters of European countries, that is, Germanic, Anglo, Nordic and more developed Latin. ${ }^{86}$ The dummy variables take the value of one if the insurer incorporated in the specified region and the value of zero otherwise. If all three dummy variables (Region1, Region2 and Region3) take the value of zero the region of incorporation is Region4. Other control variables include those for banking activity and type of insurance operations. We define a binary variable for bancassurance activities (Bank) if banking and asset management assets exceed 25 per cent of total assets. For type of insurance business, we use our Solvency I required capital proxy to determine the ratio of non-life required capital to total insurance required capital $(P \& C)$. Finally, we added four year dummy variables to control for the financial years 2005-2009 (Y2006, Y2007, Y2008 and Y2009). The dummy variables take the value of one if the annual report covers the specified financial year and the value of zero otherwise. If all four dummy variables (Y2006, Y2007, Y2008 and Y2009) take the value of zero the annual report covers the financial year 2005. Table 4 lists the regression variables, acronyms and data sources.

The study employs multiple regressions to assess the impact of size, risk, profitability and other control variables on the extent of risk disclosure. On the basis of the discussion of independent and dependent variables, the following base regression model is formulated:

$$
\begin{aligned}
\text { DScore }_{i}= & \alpha+\beta_{1} \text { MCap }_{i}+\beta_{2} \text { BtM }_{i}+\beta_{3} \text { RoE }_{i} \\
& +\beta_{4} \text { Float }_{i}+\beta_{5} \text { USList }_{i}+\beta_{6} \text { Region }_{i} \\
& +\beta_{7} \text { Region }_{i}+\beta_{8} \text { Region }_{i}+\beta_{9} \text { Bank }_{i}+\beta_{10} \text { P\&C }_{i}+\beta_{11} \text { Y2006 }_{i}+\beta_{12} \text { Y2007 }_{i}{ }^{\prime} \\
& +\beta_{13} \text { Y2008 }_{i}+\beta_{14} \text { Y2009 }_{i}+\varepsilon_{i}
\end{aligned}
$$

where $i=1, \ldots, 152$ are the insurer-year observations.

\footnotetext{
${ }^{85}$ Linsley et al. (2006, p. 275).

${ }^{86}$ Region1 (Germanic) consists of Germany, Austria and Switzerland. Region2 (Anglo) consists of Great Britain and Ireland. Region3 (Nordic) consists of the Netherlands, Denmark, Sweden and Finland. Region4 (more developed Latin) contains the Mediterranean countries of Italy, France and Spain.
} 
Table 4 Summary regression variables

\begin{tabular}{|c|c|c|c|}
\hline Variable & Acronym & Measurement & Source \\
\hline Risk disclosure & DScore & Risk disclosure index score & Authors' analysis \\
\hline Size & MCap & Logarithm of market capitalisation & Bloomberg \\
\hline Risk & BtM & Book equity/market value of equity & Annual reports, Bloomberg \\
\hline Profitability & $R o E$ & $\begin{array}{l}\text { Net profit before discontinued } \\
\text { ops./average book equity }\end{array}$ & Annual reports \\
\hline $\begin{array}{l}\text { Ownership } \\
\text { dispersion }\end{array}$ & Float & Free float in percent of total shares & Datastream \\
\hline U.S. listing & USList & $=1$ if insurer listed in the United States & $\begin{array}{l}\text { Annual reports, insurer } \\
\text { websites }\end{array}$ \\
\hline Home country & $\begin{array}{l}\text { Region1 } \\
\text { Region2 } \\
\text { Region3 }\end{array}$ & $\begin{array}{l}=1 \text { if insurer headquartered in specified } \\
\text { region }\end{array}$ & $\begin{array}{l}\text { Annual reports, insurer } \\
\text { websites }\end{array}$ \\
\hline Banking activities & Bank & $=1$ if banking assets $>25 \%$ total assets & Annual reports \\
\hline Insurance type & $P \& C$ & Solvency I required capital proxy & $\begin{array}{l}\text { Annual reports, authors' } \\
\text { analysis }\end{array}$ \\
\hline Financial year & $\begin{array}{l}Y 2006 \\
Y 2007 \\
Y 2008 \\
Y 2009\end{array}$ & $=1$ if financial year equals specified year & Annual report \\
\hline
\end{tabular}

This table lists the regression variables, acronyms and data source. DScore is the disclosure index score of our self-constructed risk disclosure index that is a number between 100 (full disclosure) and 0 (no disclosure). MCap is the logarithm of the market capitalisation of the insurer as of 31 December for each year in EUR using exchange rates as of 1 January 2005. BtM is the book value of shareholders' equity divided by the market capitalisation as of 31 December for each year. $R o E$ is the return on equity calculated as net profit attributable to shareholders before discontinued operations divided by average shareholders' equity for the financial year. Float is the free float of the insurer shares as of 31 December for each year. USList is a binary variable indicating whether an insurer has a listing on a U.S. stock exchange. Region (1,2,3) are dummy variables identifying insurers which are incorporate in the specific region. Region1 (Germanic) consists of Germany, Austria and Switzerland. Region2 (Anglo) consists of Great Britain and Ireland. Region3 (Nordic) consists of the Netherlands, Denmark, Sweden and Finland. Region4 (More developed Latin), which is omitted in the regression analysis, contains the Mediterranean countries of Italy, France and Spain. Bank is a binary variable which is set to 1 if the insurers banking and asset management assets exceed 25 per cent of its total assets. $P \& C$ is the ratio of non-life Solvency I required capital divided by total Solvency I required capital. The non-life weight was determined by 16 per cent of non-life gross premiums written. The life weight was determined by the sum of 4 per cent of gross traditional life reserves and 1 per cent of gross unit-linked reserves. $Y(2006,2007,2008,2009)$ are dummy variables identifying the financial year of the observation. Y2005 is omitted in the regression analysis.

Several tests were conducted to discover whether the assumptions of linear regression were violated. To detect a violation of the linearity assumptions, the plots of the observed vs. the predicted values were reviewed. A symmetrical distribution of observations around the diagonal line indicated no violation of the linearity assumption. An analysis of the residuals and standard tests of homoscedasticity show that the homoscedasticity assumption is violated in the case of the full sample (i.e., all years 2005-2009 considered together). We used the method of heteroscedasticitycorrected covariance matrix to correct for heteroscedasticity. Furthermore, the variables were analysed using normal probability plots and the Shapiro-Wilk test for normality was applied. To ensure rigorousness of the hypothesis tests, the market 
Table 5 Correlation matrix for the full sample 2005-2009 $(n=152)$

\begin{tabular}{|c|c|c|c|c|c|c|c|c|c|c|c|c|c|c|}
\hline & МСар & BtM & $R o E$ & Float & USList & Region1 & Region 2 & Region3 & Bank & $P \& C$ & $Y 2006$ & $Y 2007$ & $Y 2008$ & $Y 2009$ \\
\hline DScore & 0.55 & 0.18 & -0.22 & 0.43 & 0.50 & 0.13 & -0.10 & 0.23 & 0.36 & -0.15 & -0.13 & 0.05 & 0.15 & 0.21 \\
\hline MCap & & -0.30 & 0.08 & 0.24 & 0.55 & 0.03 & -0.15 & 0.03 & 0.29 & -0.33 & 0.13 & 0.09 & -0.19 & -0.07 \\
\hline BtM & & & -0.54 & 0.13 & 0.04 & 0.05 & 0.04 & -0.01 & 0.18 & -0.22 & -0.23 & -0.12 & 0.37 & 0.17 \\
\hline$R o E$ & & & & -0.15 & -0.10 & -0.07 & 0.05 & 0.12 & -0.03 & 0.42 & 0.20 & 0.15 & -0.39 & -0.10 \\
\hline Float & & & & & 0.29 & -0.01 & 0.38 & -0.03 & 0.24 & -0.26 & 0.01 & -0.01 & 0.01 & 0.00 \\
\hline USList & & & & & & -0.05 & -0.08 & 0.17 & 0.23 & -0.24 & -0.01 & -0.01 & -0.01 & 0.00 \\
\hline Region1 & & & & & & & -0.36 & -0.27 & -0.03 & -0.05 & 0.00 & 0.00 & 0.00 & 0.01 \\
\hline Region2 & & & & & & & & -0.40 & 0.06 & 0.07 & 0.01 & 0.01 & 0.01 & 0.00 \\
\hline Region 3 & & & & & & & & & 0.19 & 0.04 & -0.01 & -0.01 & -0.01 & 0.01 \\
\hline Bank & & & & & & & & & & -0.21 & 0.05 & 0.00 & -0.04 & -0.07 \\
\hline$P \& C$ & & & & & & & & & & & -0.01 & -0.01 & -0.01 & 0.01 \\
\hline$Y 2006$ & & & & & & & & & & & & -0.26 & -0.26 & -0.25 \\
\hline$Y 2007$ & & & & & & & & & & & & & -0.26 & -0.25 \\
\hline$Y 2008$ & & & & & & & & & & & & & & -0.25 \\
\hline$Y 2009$ & & & & & & & & & & & & & & \\
\hline
\end{tabular}

This table reports the correlation coefficients between the regression variables. DScore is the disclosure index score of our self-constructed risk disclosure index which is a number between 100 (full disclosure) and 0 (no disclosure). MCap is the logarithm of the market capitalisation of the insurer as of 31 December for each year in EUR using exchange rates as of 1 January 2005. BtM is the book value of shareholders' equity divided by the market capitalisation as of 31 December for each year. $R o E$ is the return on equity calculated as net profit attributable to shareholders before discontinued operations divided by average shareholders' equity for the financial year. Float is the free float of the insurer shares as of 31 December for each year. USList is a binary variable indicating whether an insurer has a listing on a U.S. stock exchange. Region (1,2,3) are dummy variables identifying insurers which are incorporate in the specific region. Region1 (Germanic) consists of Germany, Austria and Switzerland. Region2 (Anglo) consists of Great Britain and Ireland. Region3 (Nordic) consists of the Netherlands, Denmark, Sweden and Finland. Region4 (More developed Latin), which is omitted in the regression analysis, contains the Mediterranean countries of Italy, France and Spain. Bank is a binary variable which is set to 1 if the insurers banking and asset management assets exceed 25 per cent of its total assets. $P \& C$ is the ratio of non-life Solvency I required capital divided by total Solvency I required capital. The non-life weight was determined by 16 per cent of non-life gross premiums written. The life weight was determined by the sum of 4 per cent of gross traditional life reserves and 1 per cent of gross unit-linked reserves. $Y(2006,2007,2008,2009)$ are dummy variables identifying the financial year of the observation. Y2005 is omitted in the regression analysis.

capitalisation data is log transformed. Analysis of the normal probability plot of the residuals and the chi-squared test for normality of the residuals confirmed that the normal distribution assumption is not violated. To test whether the problem of multicollinearity exists, implying that two or more independent variables are highly correlated, the correlation matrix and the variance inflation factors (VIFs) were reviewed. There is no standard cut-off point for correlation coefficients or for independent variables' VIFs. As a general rule of thumb, however, correlation greater than 0.7 and VIFs greater than 10 can indicate a multicollinearity problem. ${ }^{87}$ Our analysis shows that all correlation coefficients between independent variables are between -0.5 and +0.6 (Table 5) and that the individual VIFs are below 3.0 (Table 6), indicating that multicollinearity is highly unlikely.

${ }^{87}$ See Wissmann et al. (2007) and O'Brien (2007). 
Table 6 Variance inflation factors for the full sample 2005-2009 $(n=152)$

\begin{tabular}{ll}
\hline Variable & VIF \\
\hline MCap & 2.370 \\
BtM & 2.024 \\
RoE & 1.948 \\
Float & 1.651 \\
USList & 1.661 \\
Region1 & 1.705 \\
Region2 & 2.633 \\
Region3 & 2.027 \\
Bank & 1.388 \\
Y2C & 1.562 \\
Y2007 & 1.644 \\
Y2008 & 1.654 \\
Y2009 & 2.065 \\
\hline
\end{tabular}

This table reports the variance inflation factors of the independent regression variables. MCap is the logarithm of the market capitalisation of the insurer as of 31 December for each year in EUR using exchange rates as of 1 January 2005. BtM is the book value of shareholders' equity divided by the market capitalisation as of 31 December for each year. $R o E$ is the return on equity calculated as net profit attributable to shareholders before discontinued operations divided by average shareholders' equity for the financial year. Float is the free float of the insurer shares as of 31 December for each year. USList is a binary variable indicating whether an insurer has a listing on a U.S. stock exchange. Region (1,2,3) are dummy variables identifying insurers which are incorporate in the specific region. Region1 (Germanic) consists of Germany, Austria and Switzerland. Region2 (Anglo) consists of Great Britain and Ireland. Region3 (Nordic) consists of the Netherlands, Denmark, Sweden and Finland. Region4 (More developed Latin), which is omitted in the regression analysis, contains the Mediterranean countries of Italy, France and Spain. Bank is a binary variable which is set to 1 if the insurers banking and asset management assets exceed 25 per cent of its total assets. $P \& C$ is the ratio of non-life Solvency I required capital divided by total Solvency I required capital. The non-life weight was determined by 16 per cent of non-life gross premiums written. The life weight was determined by the sum of 4 per cent of gross traditional life reserves and 1 per cent of gross unit-linked reserves. $Y(2006,2007,2008,2009)$ are dummy variables identifying the financial year of the observation. Y2005 is omitted in the regression analysis.

Descriptive statistics for the regression variables are provided in Table 7 and Table 8.

\section{Empirical results and discussion}

A first analysis of the location of risk reporting in the annual reports highlights the increased importance of risk disclosure. We find a trend towards more prominent risk reporting in the management commentary preceding the financial statements in insurer annual reports. Only 57 per cent of insurers provided a discussion of risks in the management commentary in 2005; this number increased to 86 per cent in 2009 (Figure 1). The average number of risk reporting pages doubled from 13 in 2005 to 26 in 2009 (Figure 2).

Analysis of the extent of risk disclosure shows a significant upsurge. The average DScore increased from 28 in 2005 to 41 in 2009. However, the average level of risk 
Table 7 Descriptive statistics for independent binary variables

\begin{tabular}{|c|c|c|c|c|c|c|c|c|c|c|c|c|}
\hline \multirow[t]{2}{*}{ Variable } & \multicolumn{2}{|c|}{$\begin{array}{c}\text { Frequency } \\
2005-09 \\
(n=152)\end{array}$} & \multicolumn{2}{|c|}{$\begin{array}{c}\text { Frequency } \\
2005 \\
(n=30)\end{array}$} & \multicolumn{2}{|c|}{$\begin{array}{c}\text { Frequency } \\
2006 \\
(n=31)\end{array}$} & \multicolumn{2}{|c|}{$\begin{array}{c}\text { Frequency } \\
2007 \\
(n=31)\end{array}$} & \multicolumn{2}{|c|}{$\begin{array}{c}\text { Frequency } \\
2008 \\
(n=31)\end{array}$} & \multicolumn{2}{|c|}{$\begin{array}{c}\text { Frequency } \\
2009 \\
(n=29)\end{array}$} \\
\hline & Absolute & $\%$ & Absolute & $\%$ & Absolute & $\%$ & Absolute & $\%$ & Absolute & $\%$ & Absolute & $\%$ \\
\hline USList & 26 & 17 & 6 & 20 & 5 & 16 & 5 & 16 & 5 & 16 & 5 & 1 \\
\hline Region1 & 30 & 20 & 6 & 20 & 6 & 19 & 6 & 19 & 6 & 19 & 6 & 21 \\
\hline Region 2 & 53 & 35 & 10 & 33 & 11 & 35 & 11 & 35 & 11 & 35 & 10 & 34 \\
\hline Region3 & 35 & 23 & 7 & 23 & 7 & 23 & 7 & 23 & 7 & 23 & 7 & 24 \\
\hline Bank & 24 & 16 & 6 & 20 & 6 & 19 & 5 & 16 & 4 & 13 & 3 & 10 \\
\hline$Y 2006$ & 31 & 21 & 0 & 0 & 31 & 100 & 0 & 0 & 0 & 0 & 0 & 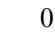 \\
\hline$Y 2007$ & 31 & 21 & 0 & 0 & 0 & 0 & 31 & 100 & 0 & 0 & 0 & \\
\hline$Y 2008$ & 31 & 21 & 0 & 0 & 0 & 0 & 0 & 0 & 31 & 100 & 0 & \\
\hline$Y 2009$ & 29 & 19 & 0 & 0 & 0 & 0 & 0 & 0 & 0 & 0 & 29 & 100 \\
\hline
\end{tabular}

This table reports the descriptive statistics for the independent binary regression variables. USList is a binary variable indicating whether an insurer has a listing on a U.S. stock exchange. Region $(1,2,3)$ are dummy variables identifying insurers which are incorporate in the specific region. Region1 (Germanic) consists of Germany, Austria and Switzerland. Region2 (Anglo) consists of Great Britain and Ireland. Region3 (Nordic) consists of the Netherlands, Denmark, Sweden and Finland. Region4 (More developed Latin), which is omitted in the regression analysis, contains the Mediterranean countries of Italy, France and Spain. Bank is a binary variable which is set to 1 if the insurers banking and asset management assets exceed 25 per cent of its total assets. $Y(2006,2007,2008,2009)$ are dummy variables identifying the financial year of the observation. $Y 2005$ is omitted in the regression analysis.

disclosure is still moderate compared to the risk disclosure index benchmark of 100 and the DScore of a hypothetical combined best practice insurer of 87 in 2005 and 100 in $2009 .^{88}$ There is a large gap between the best and the worst insurers in terms of risk reporting, a gap that increases during the sample period. The best insurer scores 47 in 2005 and 78 in 2009, whereas the worst insurer only achieved nine in 2005 and 23 in 2009. Our results reflect the statements of IAIS, ${ }^{4} \mathrm{KPMG}^{5}$ and PricewaterhouseCoopers ${ }^{6}$ regarding the lack of transparency in insurer risk reporting and are comparable to the results of Kraft and Nolte ${ }^{11}$ for their sample of German insurers from 1999 to 2003. Table 9 reports descriptive statistics for the disclosure score.

Over the sample period (2005-2009), the insurers improved their risk disclosures in all risk categories. The seven risk subindices are positively correlated on a 1 per cent level for the full sample 2005-2009. Overall, the insurers focused their attention on aggregated risk overview and operational risk. The scores for both subindices increased by 17 per cent and 21 per cent per annum, respectively, during the sample period. The reasons for the major improvement in these two subindices have to do with the increasing importance of consolidated risk measures and the increasing

\footnotetext{
${ }^{88}$ The combined best practice insurer combines the best reporting standards of the sample insurers for each item for each year.
} 
Table 8 Descriptive statistics for independent non-binary variables

\begin{tabular}{|c|c|c|c|c|c|c|}
\hline Variable & Year & $n$ & Min & $\operatorname{Max}$ & Mean & Std. Dev. \\
\hline $\operatorname{Exp}($ MCap $)$ & 2005-2009 & 152 & 435 & 74,069 & 13,212 & 16,443 \\
\hline \multirow[t]{5}{*}{ (EUR mn) } & 2005 & 30 & 1,075 & 64,598 & 14,636 & 18,123 \\
\hline & 2006 & 31 & 1,470 & 74,069 & 17,237 & 20,568 \\
\hline & 2007 & 31 & 1,021 & 66,600 & 15,978 & 18,797 \\
\hline & 2008 & 31 & 435 & 33,979 & 7,934 & 9,299 \\
\hline & 2009 & 29 & 878 & 39,557 & 10,123 & 11,139 \\
\hline BtM & 2005-2009 & 152 & 0.1 & 5.4 & 0.9 & 0.6 \\
\hline \multirow[t]{5}{*}{ (Decimals) } & 2005 & 30 & 0.2 & 1.0 & 0.6 & 0.2 \\
\hline & 2006 & 31 & 0.1 & 1.0 & 0.6 & 0.2 \\
\hline & 2007 & 31 & 0.1 & 1.6 & 0.7 & 0.3 \\
\hline & 2008 & 31 & 0.1 & 5.4 & 1.3 & 1.0 \\
\hline & 2009 & 29 & 0.1 & 2.4 & 1.1 & 0.5 \\
\hline$R o E$ & 2005-2009 & 152 & -24 & 56 & 14 & 13 \\
\hline \multirow[t]{5}{*}{$(\%)$} & 2005 & 30 & 2 & 52 & 17 & 10 \\
\hline & 2006 & 31 & 9 & 52 & 19 & 9 \\
\hline & 2007 & 31 & -2 & 56 & 17 & 11 \\
\hline & 2008 & 31 & -24 & 56 & 4 & 14 \\
\hline & 2009 & 29 & -14 & 54 & 11 & 13 \\
\hline Float & 2005-2009 & 152 & 22 & 100 & 80 & 23 \\
\hline \multirow[t]{5}{*}{$(\%)$} & 2005 & 30 & 26 & 100 & 79 & 22 \\
\hline & 2006 & 31 & 29 & 100 & 80 & 23 \\
\hline & 2007 & 31 & 25 & 100 & 79 & 24 \\
\hline & 2008 & 31 & 25 & 100 & 80 & 22 \\
\hline & 2009 & 29 & 22 & 100 & 80 & 24 \\
\hline$P \& C$ & 2005-2009 & 152 & 0 & 100 & 37 & 36 \\
\hline \multirow{5}{*}{$(\%)$} & 2005 & 30 & 0 & 100 & 37 & 36 \\
\hline & 2006 & 31 & 0 & 100 & 36 & 36 \\
\hline & 2007 & 31 & 0 & 100 & 36 & 36 \\
\hline & 2008 & 31 & 0 & 100 & 36 & 37 \\
\hline & 2009 & 29 & 0 & 100 & 38 & 37 \\
\hline
\end{tabular}

This table reports the descriptive statistics for the independent non-binary regression variables. MCap is the logarithm of the market capitalisation of the insurer as of 31 December for each year in EUR using exchange rates as of 1 January 2005. BtM is the book value of shareholders' equity divided by the market capitalisation as of 31 December for each year. $R o E$ is the return on equity calculated as net profit attributable to shareholders before discontinued operations divided by average shareholders' equity for the financial year. Float is the free float of the insurer shares as of 31 December for each year. $P \& C$ is the ratio of non-life Solvency I required capital divided by total Solvency I required capital. The non-life weight was determined by 16 per cent of non-life gross premiums written. The life weight was determined by the sum of 4 per cent of gross traditional life reserves and 1 per cent of gross unit-linked reserves.

regulatory emphasis on operational risk since the adoption of Basel II. ${ }^{89}$ In 2007, very likely induced by the new IFRS 7 disclosure requirements for financial instruments, the average disclosure scores in the subindices risk overview, market risk, credit risk and liquidity risk improved significantly. Table 10 reports the average disclosure

${ }^{89}$ See Helbok and Wagner (2006). 


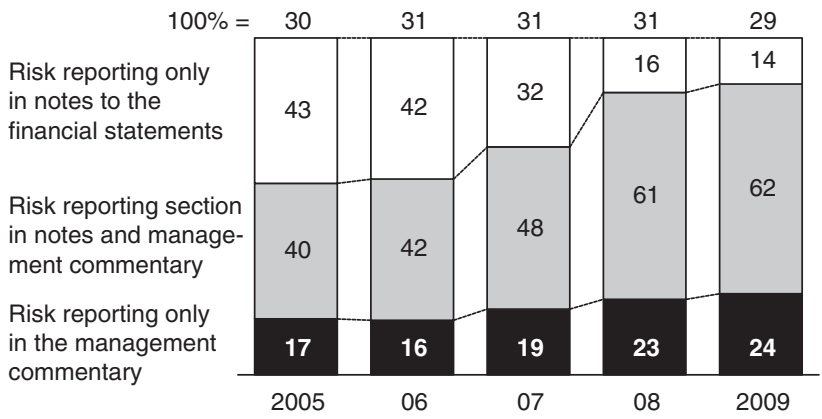

Figure 1. Location of risk reporting in insurers annual reports.

Note: This figure shows the percentage of annual reports that consists of a risk analysis and discussion section located in the notes to the financial statements, the management commentary of the annual report or both.

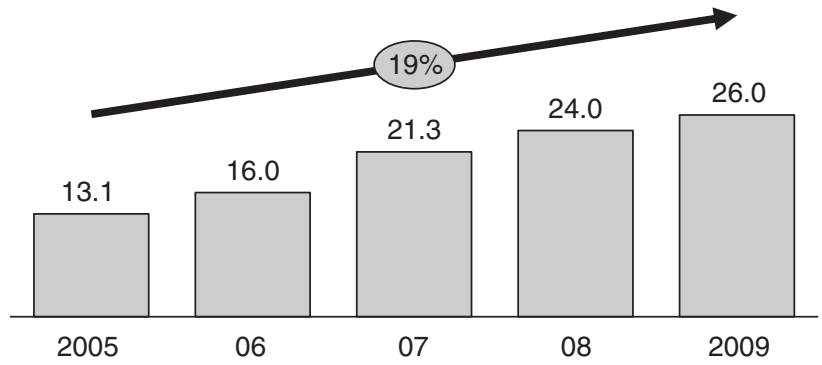

Figure 2. Average number of pages in insurers' risk reports.

Note: This figure shows the average number of pages in insurers' risk reports. The growth rate displays the compound annual growth in the average number of risk report pages.

scores and growth rates for each of the seven subindices of our self-constructed risk disclosure index.

The $F$-statistic $=27$ for the multiple on the full sample of all 152 annual reports from 2005 to 2009 is significant on a 1 per cent level, implying that at least one of the coefficients is linearly associated with the dependent variable. The adjusted $R^{2}=0.73$, indicating that about 73 per cent of the dependent variable variance is explained by the independent variables. Table 11 reports the results from our multiple regression analysis.

The coefficient estimate for the logarithm of year-end market capitalisation, which is our proxy for insurer size, is positive and statistically significant. This, along with other empirical research, supports our first hypothesis $(\mathrm{H} 1)$ of a positive relationship between size and the extent of risk disclosure, based on increasing agency, information and political costs as well as better access to required reporting resources. Year-end total assets as an alternative measure of insurer size yields comparable results.

The coefficient for our proxy for insurer risk - year-end book-to-market ratio - is positive and statistically significant. This supports our second hypothesis $(\mathrm{H} 2)$. The 
The Geneva Papers on Risk and Insurance-Issues and Practice

404

Table 9 Descriptive statistics for risk disclosure score

\begin{tabular}{|c|c|c|c|c|c|c|c|c|c|}
\hline \multirow[t]{2}{*}{ Variable } & \multirow[t]{2}{*}{ Year } & \multirow[t]{2}{*}{$n$} & \multirow[t]{2}{*}{ Mean } & \multirow[t]{2}{*}{ Std. Dev } & \multirow[t]{2}{*}{ Min } & \multicolumn{3}{|c|}{ Percentile } & \multirow[t]{2}{*}{$\operatorname{Max}$} \\
\hline & & & & & & $25 \%$ & $50 \%$ & $75 \%$ & \\
\hline \multirow[t]{6}{*}{ DScore } & 2005-09 & 152 & 35 & 14 & 9 & 25 & 33 & 42 & 78 \\
\hline & 2005 & 30 & 28 & 11 & 9 & 22 & 25 & 36 & 47 \\
\hline & 2006 & 31 & 32 & 11 & 12 & 24 & 30 & 38 & 56 \\
\hline & 2007 & 31 & 37 & 14 & 19 & 27 & 35 & 41 & 71 \\
\hline & 2008 & 31 & 39 & 14 & 20 & 30 & 38 & 44 & 77 \\
\hline & 2009 & 29 & 41 & 14 & 23 & 30 & 40 & 45 & 78 \\
\hline
\end{tabular}

This table reports descriptive statistics for the dependent variable of our regression model. DScore is the disclosure index score of our self-constructed risk disclosure index which is a number between 100 (full disclosure) and 0 (no disclosure).

Table 10 Average disclosure score for risk subindices

\begin{tabular}{lcccccccc}
\hline Year & $n$ & $\begin{array}{c}\text { Risk } \\
\text { overview }\end{array}$ & $\begin{array}{c}\text { Underwriting } \\
\text { risk }\end{array}$ & $\begin{array}{c}\text { Market } \\
\text { risk }\end{array}$ & $\begin{array}{c}\text { Credit } \\
\text { risk }\end{array}$ & $\begin{array}{c}\text { Operational } \\
\text { risk }\end{array}$ & $\begin{array}{c}\text { Liquidity } \\
\text { risk }\end{array}$ & $\begin{array}{c}\text { Other } \\
\text { risks }\end{array}$ \\
\hline 2005 & 30 & 19 & 36 & 36 & 30 & 13 & 30 & 22 \\
2006 & 31 & 22 & 41 & 41 & 31 & 20 & 34 & 32 \\
2007 & 31 & 31 & 45 & 44 & 35 & 22 & 42 & 34 \\
2008 & 31 & 34 & 46 & 47 & 37 & 26 & 44 & 50 \\
2009 & 29 & 36 & 47 & 49 & 38 & 28 & 48 & 52 \\
CAGR & 17 & 7 & 8 & 6 & 21 & 12 & 24 \\
\hline
\end{tabular}

This table reports the average disclosure scores for each of the seven subindices of our self-constructed risk disclosure index. The Score for each subindex is a number between 100 (full disclosure) and 0 (no disclosure). $C A G R$ is the compound annual growth rate of the average disclosure score for each of the seven subindices.

findings indicate that insurers tend to increase their risk reporting to reduce the contracting costs associated with higher levels of perceived riskiness.

The negative and statistically significant coefficient for return on equity, which is our proxy for insurer profitability, supports our third hypothesis (H3) that there is a negative relationship between the extent of risk disclosure and profitability. In line with the results of Helbok and Wagner ${ }^{24}$ and Vandemaele et al. (2009), ${ }^{90}$ it seems that stakeholders interpret profitability as an important proxy for whether the insurer will be able to generate capital and restore equity. Hence, poor performance increases public pressure to explain inherent risks. Return on assets as an alternative measure of insurer profitability yields comparable results.

The coefficient for free float as our proxy for ownership dispersion is positive and statistically significant, supporting our fourth hypothesis (H4). In line with other empirical research, we argue that contracting costs increase with greater ownership dispersion due to higher level of agency costs and increased public scrutiny. Insurers are motivated to counter these increasing costs with more disclosure.

\footnotetext{
${ }^{90}$ Vandemaele et al. (2009).
} 
Table 11 Multiple regression results

\begin{tabular}{|c|c|c|c|}
\hline Variable & Predicted sign & $2005-2009(n=152)$ & $p$-value \\
\hline Constant & & $-0.51^{* * *}$ & 0.00 \\
\hline MCap & + & $0.07 * * *$ & 0.00 \\
\hline BtM & + & $0.02 *$ & 0.07 \\
\hline$R o E$ & - & $-0.19 * * *$ & 0.00 \\
\hline Float & + & $0.14 * * *$ & 0.00 \\
\hline USList & + & $0.04 *$ & 0.10 \\
\hline Region1 & $+/-$ & $0.08 * * *$ & 0.00 \\
\hline Region2 & $+/-$ & 0.03 & 0.11 \\
\hline Region3 & $+1-$ & $0.09 * * *$ & 0.00 \\
\hline Bank & + & $0.05 * *$ & 0.03 \\
\hline$P \& C$ & $+1-$ & $0.09 * * *$ & 0.00 \\
\hline$Y 2006$ & + & $0.03 *$ & 0.07 \\
\hline$Y 2007$ & + & $0.08 * * *$ & 0.00 \\
\hline$Y 2008$ & + & $0.12 * * *$ & 0.00 \\
\hline$Y 2009$ & + & $0.13^{* * *}$ & 0.00 \\
\hline F-statistic & & $27 * * *$ & 0.00 \\
\hline Adj. $R^{2}$ & & 0.73 & \\
\hline
\end{tabular}

This table reports results from our multiple regression analysis. Constant is the intercept of our regression function. MCap is the logarithm of the market capitalisation of the insurer as of 31 December for each year in EUR using exchange rates as of 1 January 2005. BtM is the book value of shareholders' equity divided by the market capitalisation as of 31 December for each year. $R o E$ is the return on equity calculated as net profit attributable to shareholders before discontinued operations divided by average shareholders' equity for the financial year. Float is the free float of the insurer shares as of 31 December for each year. USList is a binary variable indicating whether an insurer has a listing on a U.S. stock exchange. Region $(1,2,3)$ are dummy variables identifying insurers which are incorporate in the specific region. Region1 (Germanic) consists of Germany, Austria and Switzerland. Region2 (Anglo) consists of Great Britain and Ireland. Region3 (Nordic) consists of the Netherlands, Denmark, Sweden and Finland. Region4 (More developed Latin), which is omitted in the regression analysis, contains the Mediterranean countries of Italy, France and Spain. Bank is a binary variable which is set to 1 if the insurers banking and asset management assets exceed 25 per cent of its total assets. $P \& C$ is the ratio of non-life Solvency I required capital divided by total Solvency I required capital. The non-life weight was determined by 16 per cent of non-life gross premiums written. The life weight was determined by the sum of 4 per cent of gross traditional life reserves and 1 per cent of gross unit-linked reserves. $Y(2006,2007,2008,2009)$ are dummy variables identifying the financial year of the observation. Y2005 is omitted in the regression analysis.

$*$, ** and $* * *$ denote the level of significance 10 per cent, 5 per cent and 1 per cent, respectively.

The coefficient for the binary variable of cross-listing on a U.S. stock exchange is positive and statistically significant. This supports our fifth hypothesis (H5) that cross-listing on a U.S. stock exchange has a significant influence on risk disclosure. The positive coefficient indicates that higher regulatory disclosure requirements and higher agency costs associated with foreign listing result in higher levels of risk reporting. However, the administrative costs associated with a listing on a U.S. stock exchange are burdensome; indeed, in 2009, Allianz SE and AXA SA both decided to delist from the NYSE.

Our findings indicate that cultural differences in accounting, regulatory and market practices result in different degrees of risk disclosure (H6). Similar to Woods et al., ${ }^{25}$ 
we find that Mediterranean countries (Italy, Spain and France) have lower levels of risk disclosure compared to other European countries. The Nordic countries (Netherlands, Denmark, Finland and Sweden) and the Western Central European countries (Germany, Austria and Switzerland) appear to have higher levels of risk disclosure.

The coefficient for the binary variable classifying insurers as active in banking is positive and statistically significant. This supports our seventh hypothesis $(\mathrm{H} 7)$ that banking and asset management have a significant influence on risk disclosure. The positive coefficient indicates that the higher regulatory disclosure requirements for banks induce enhanced risk disclosure.

The coefficient for the importance of non-life business to an insurer is positive and statistically significant, implying that non-life insurers or composite insurers with a major focus on non-life business on average score higher in our risk disclosure index, controlling for other independent variables. One possible reason for this finding may be that the complexity of the life business requires more expensive and sophisticated risk management and reporting systems, which may outweigh the benefits of disclosing more information. Moreover, risk information for life insurance business may be proprietary, making insurers reluctant to provide as much risk disclosure as do insurers engaged in the non-life business. We have to reject our hypothesis (H8) that there is no relationship between the extent of risk disclosure and the importance of non-life business to an insurer.

We performed a regression on ranked variables, which assumes no functional form, as a robustness check and a two-way fixed-effects covariance model with pooled (panel) data regression, which provided mostly similar results. The coefficients for cross-listing in the United States and the existence of bancassurance activities indicate similar relationships, however, with lower levels of significance. Table 12 reports the results from our multiple regression analysis on ranked variables and for pooled (panel) data.

In addition, we split the sample into two subsamples, including annual report before and after the introduction of IFRS 7 in 2007 and performed separate regression analyses to substantiate whether the introduction of IFRS 7 had a significant impact on the relationship between risk disclosure and the independent variables. The results indicate that the general relationship between risk disclosure and the independent variables does not depend on the subsample chosen. However, the level of significance is generally higher for the larger subsample 2007-2009 $(n=91)$. Table 13 reports the regression results on both subsamples.

\section{Conclusion}

This paper investigates risk disclosure practices in annual reports of European insurers listed on the Dow Jones Stoxx 600 Insurance Index during the period 2005-2009. A self-constructed risk disclosure index is employed to provide a comprehensive picture of the extent and development of European insurers' risk disclosure and to empirically test the relationships between the extent of risk disclosure and characteristics of the sampled insurers. On the basis of positive accounting theory, hypotheses as to the 
Table 12 Results of multiple regression on ranked variables and of two-way fixed-effects covariance model with pooled (panel) data for the time period 2005-2009 $(n=152)$

\begin{tabular}{|c|c|c|c|c|c|}
\hline Variable & Predict sign & Ranked variables & p-value & Pooled (panel) data & $p$-value \\
\hline Constant & & $39.94 * * *$ & 0.00 & $-0.54 * * *$ & 0.00 \\
\hline MCap & + & $0.54 * * *$ & 0.00 & $0.08 * * *$ & 0.00 \\
\hline BtM & + & $0.10^{*}$ & 0.10 & $0.03 *$ & 0.07 \\
\hline$R o E$ & - & $-0.17 * * *$ & 0.01 & $-0.21 * * *$ & 0.00 \\
\hline Float & + & $0.27 * * *$ & 0.00 & $0.10 * * *$ & 0.00 \\
\hline USList & + & 10.06 & 0.13 & 0.03 & 0.24 \\
\hline Region1 & $+1-$ & $17.51^{* * *}$ & 0.00 & $0.10 * * *$ & 0.00 \\
\hline Region2 & $+1-$ & $14.59 * *$ & 0.02 & $0.06^{* *}$ & 0.02 \\
\hline Region3 & $+1-$ & $38.04 * * *$ & 0.00 & $0.15^{* * *}$ & 0.00 \\
\hline Bank & + & 6.24 & 0.33 & $0.05 * * *$ & 0.00 \\
\hline$P \& C$ & $+1-$ & $0.22 * * *$ & 0.00 & $0.09 * * *$ & 0.00 \\
\hline$Y 2006$ & + & $10.13^{*}$ & 0.10 & -0.00 & 0.84 \\
\hline$Y 2007$ & + & $22.47 * * *$ & 0.00 & 0.02 & 0.40 \\
\hline$Y 2008$ & + & $33.12 * * *$ & 0.00 & 0.01 & 0.55 \\
\hline$Y 2009$ & + & $35.91 * * *$ & 0.00 & 0.01 & 0.60 \\
\hline F-statistic & & $25^{* * *}$ & 0.00 & $9 * * *$ & 0.00 \\
\hline Adj. $R^{2}$ & & 0.69 & & 0.73 & \\
\hline
\end{tabular}

This table reports results from our multiple regression analysis on ranked variables and for pooled (panel) data. Constant is the intercept of our regression function. MCap is the logarithm of the market capitalisation of the insurer as of 31 December for each year in EUR using exchange rates as of 1 January 2005. BtM is the book value of shareholders' equity divided by the market capitalisation as of 31 December for each year. $R o E$ is the return on equity calculated as net profit attributable to shareholders before discontinued operations divided by average shareholders' equity for the financial year. Float is the free float of the insurer shares as of 31 December for each year. USList is a binary variable indicating whether an insurer has a listing on a U.S. stock exchange. Region (1,2,3) are dummy variables identifying insurers which are incorporate in the specific region. Regionl (Germanic) consists of Germany, Austria and Switzerland. Region2 (Anglo) consists of Great Britain and Ireland. Region3 (Nordic) consists of the Netherlands, Denmark, Sweden and Finland. Region4 (More developed Latin), which is omitted in the regression analysis, contains the Mediterranean countries of Italy, France and Spain. Bank is a binary variable which is set to 1 if the insurers banking and asset management assets exceed 25 per cent of its total assets. $P \& C$ is the ratio of non-life Solvency I required capital divided by total Solvency I required capital. The non-life weight was determined by 16 per cent of non-life gross premiums written. The life weight was determined by the sum of 4 per cent of gross traditional life reserves and 1 per cent of gross unit-linked reserves. $Y(2006,2007,2008,2009)$ are dummy variables identifying the financial year of the observation. $Y 2005$ is omitted in the regression analysis.

*, ** and *** denote the level of significance 10 per cent, 5 per cent and 1 per cent, respectively.

relationship between extent of risk disclosure and size, risk, profitability, ownership dispersion, listing status, home country, bancassurance activity and one of business type are developed.

We find that the importance of risk disclosure in the annual reports increased substantially with regard to extent of disclosure and its location in the reports. The introduction of IFRS 7, Basel II and the financial crisis potentially triggered this improvement in risk disclosure. Aggregated risk overview and operational risk reporting received the most attention with the highest growth rates. Nevertheless, risk 
Table 13 Results of multiple regression on subsample data for the time periods 2005-2006 $(n=61)$ and 2007-2009 $(n=91)$

\begin{tabular}{|c|c|c|c|c|c|}
\hline Variable & Predicted sign & Before 2007 & p-value & After 2007 & $p$-value \\
\hline Constant & & $-0.40 * * *$ & 0.00 & $-0.50 * * *$ & 0.00 \\
\hline MCap & + & $0.06^{* * *}$ & 0.00 & $0.07 * * *$ & 0.00 \\
\hline BtM & + & 0.05 & 0.45 & $0.03 * *$ & 0.04 \\
\hline$R o E$ & - & -0.18 & 0.22 & $-0.24 * * *$ & 0.00 \\
\hline Float & + & $0.09 * *$ & 0.01 & $0.16^{* * *}$ & 0.00 \\
\hline USList & + & 0.02 & 0.66 & $0.05^{*}$ & 0.10 \\
\hline Region1 & $+1-$ & $0.05^{* *}$ & 0.03 & $0.10 * * *$ & 0.00 \\
\hline Region2 & $+1-$ & 0.05 & 0.12 & 0.02 & 0.50 \\
\hline Region3 & $+1-$ & $0.10 * * *$ & 0.00 & $0.10 * * *$ & 0.00 \\
\hline Bank & + & 0.01 & 0.75 & $0.08 * * *$ & 0.00 \\
\hline$P \& C$ & $+1-$ & $0.05^{*}$ & 0.10 & $0.14 * * *$ & 0.00 \\
\hline F-statistic & & $14 * * *$ & 0.00 & $29 * * *$ & 0.00 \\
\hline Adj. $R^{2}$ & & 0.66 & & 0.73 & \\
\hline$n$ & & 61 & & 91 & \\
\hline
\end{tabular}

This table reports results from our multiple regression analysis on subsample data for the time periods 2005-2006 and 2007-2009. Constant is the intercept of our regression function. MCap is the logarithm of the market capitalisation of the insurer as of 31 December for each year in EUR using exchange rates as of 1 January 2005. BtM is the book value of shareholders' equity divided by the market capitalisation as of 31 December for each year. $R o E$ is the return on equity calculated as net profit attributable to shareholders before discontinued operations divided by average shareholders' equity for the financial year. Float is the free float of the insurer shares as of 31 December for each year. USList is a binary variable indicating whether an insurer has a listing on a U.S. stock exchange. Region (1,2,3) are dummy variables identifying insurers which are incorporate in the specific region. Region1 (Germanic) consists of Germany, Austria and Switzerland. Region2 (Anglo) consists of Great Britain and Ireland. Region3 (Nordic) consists of the Netherlands, Denmark, Sweden and Finland. Region4 (More developed Latin), which is omitted in the regression analysis, contains the Mediterranean countries of Italy, France and Spain. Bank is a binary variable which is set to 1 if the insurers banking and asset management assets exceed 25 per cent of its total assets. $P \& C$ is the ratio of non-life Solvency I required capital divided by total Solvency I required capital. The non-life weight was determined by 16 per cent of non-life gross premiums written. The life weight was determined by the sum of 4 per cent of gross traditional life reserves and 1 per cent of gross unit-linked reserves. $*$, ** and $* * *$ denote the level of significance 10 per cent, 5 per cent and 1 per cent, respectively.

disclosure by the European insurance industry remains moderate on average, but with strong variation among the sample insurers.

The regression results show a significant positive relationship between the extent of risk disclosure and insurer size, which is as expected by positive accounting theory and confirmed by other empirical research. We find a significant positive relationship between insurer risk and risk disclosure and a significant negative relationship between degree of risk disclosure and insurer profitability. We confirm the positive influence of cross-listing status and ownership dispersion on the extent of risk disclosure. Furthermore, we find evidence of inter-insurer and inter-country differences in risk disclosure practices.

There are several limitations inherent to the design of our study. Although coding of insurer annual reports was done by a single coder using an item checklist, decision rules were amplified by specific examples, and inter-rater reliability tests were 
conducted in an effort to ensure uniform coding, the procedure remains inevitably subjective. Similarly, despite the use of current industry and market perspectives on best practice risk reporting for insurers, construction of the disclosure index and determination of the scoring decision rules are both also subjective and limit the general applicability of our conclusions. Furthermore, there may be factors that influence the extent of risk disclosure that we did not take into account. For example, product and regional diversification, corporate governance characteristics, or analyst following could have been, but were not, used as variables. Owing to the time-consuming process of data collection and coding, the sample was relatively small. Finally, our sample is unavoidably affected by survivorship bias. Interesting avenues for future research include collection of more extensive data and application of our disclosure index to other regions of the world, such as Asia and the United States.

Our study shows that European insurers are preparing themselves for the upcoming Solvency II Pillar 3 requirements; the extent of risk disclosure increased significantly during the last five years. However, three out of the top ten insurers in terms of risk disclosure required state support in form of capital injections during the 2008 financial crisis, raising the question whether market discipline is effective in the European insurance industry. Nier and Baumann ${ }^{18}$ state that three conditions are necessary for market discipline to be effective. First, stakeholders need to consider themselves at risk of loss in case of default. Second, stakeholders' response to changes in the risk profile needs to have cost implications for insurers. Third, the market must have adequate information to judge the riskiness of the insurer. Our paper reveals that a lack of risk transparency is a potential impediment to market discipline in the European insurance industry. There is still a large gap to be bridged before good risk reporting practice becomes standard (and expected) practice. Despite efforts made towards an international accounting and regulatory harmonisation, there are still large interinsurer and inter-cultural differences in risk disclosure. Moreover, our analysis indicates that insurers tend to improve their risk reporting ex-post due to market pull in uncertain times with high risks and low profitability. However, an increase in the amount of risk disclosures may not necessarily increase transparency. Transparency, comparability, understandability and accessibility are crucial to the success of public risk disclosure facilitating effective market discipline. ${ }^{91}$ Higher minimum regulatory requirements in a more standardised format would support risk transparency.

The new regulatory disclosure requirements have the potential to significantly enhance the average levels of risk disclosure in the European insurance industry from their current mediocrity by requiring, for example, more quantitative and comparable risk information (e.g., same $\mathrm{VaR}$ measure and confidence interval). However, the benefits of increased reporting requirements must be compared to their costs. A recent PricewaterhouseCoopers survey of 120 insurers in the United Kingdom revealed these insurers' major concern with supervisory disclosure requirements: the volume of information asked for and the lack of harmonisation with other reporting requirements. ${ }^{92}$ Solvency II provides a great opportunity for comparable and transparent risk

\footnotetext{
${ }^{91}$ See CRO Forum (2008, p. 5), Eling and Schmeiser (2010, p. 25) and De Mey (2009, pp. 230-233).

${ }^{92}$ See Insurance Age (2009).
} 
disclosure requirements, which will enhance stakeholder confidence. However, to make this opportunity a reality, the insurance industry must be convinced that these benefits will outweigh the costs.

\section{References}

Abraham, S. and Cox, P. (2007) 'Analysing the determinants of narrative risk information in UK FTSE 100 annual reports', British Accounting Review 39(3): 227-248.

Adams, M. and Hossain, M. (1998) 'Managerial discretion and voluntary disclosure: Empirical evidence from the New Zealand life insurance industry', Journal of Accounting and Public Policy 17(3): 245-281.

Ahmed, K. and Courtis, J.K. (1999) 'Associations between corporate characteristics and disclosure levels in annual reports: A meta-analysis', British Accounting Review 31(1): 35-61.

Ali, M. (2005) 'Corporate risk reporting practices in annual reports of Japanese companies', Journal of the Japanese Association for International Accounting Studies March(2005): 113-133.

Amran, A., Manaf Rosli Bin, A. and Hassan, B.C.H.M. (2009) 'Risk reporting - An exploratory study on risk management disclosure in Malaysian annual reports', Managerial Auditing Journal 24(1): 39-57.

Barako, D.G., Hancock, P. and Izan, H.Y. (2006) 'Factors influencing voluntary corporate disclosure by Kenyan companies', Corporate Governance: An International Review 14(2): 107-125.

Baumann, U. and Nier, E. (2004) 'Disclosure, volatility, and transparency: An empirical investigation into the value of bank disclosure', FRBNY Economic Policy Review 10(2): 31-45.

Beattie, V., McInnes, B. and Fearnley, S. (2004) 'A methodology for analysing and evaluating narratives in annual reports: A comprehensive descriptive profile and metrics for disclosure quality attributes', Accounting Forum 28(3): 205-236.

Beretta, S. and Bozzolan, S. (2004) 'A framework for the analysis of firm risk communication', International Journal of Accounting 39(3): 265-288.

Beretta, S. and Bozzolan, S. (2008) 'Quality versus quantity: The case of forward- looking disclosure', Journal of Accounting, Auditing and Finance 23(3): 333-375.

Boston Consulting Group [BCG] (2008) 'Creating competitive advantage-The European insurance landscape, from http://www.bcg.com/documents/file15193.pdf, accessed 22 March 2010.

Botosan, C.A. (1997) 'Disclosure level and the cost of equity capital', Accounting Review 72: 323-349.

CEIOPS (2008) 'CEIOPS' Report on Its Fourth Quantitative Impact Study (QIS4) for Solvency II-Annex of Selected Tables, from https://eiopa.europa.eu/fileadmin/tx_dam/files/consultations/QIS/CEIOPS-SEC-8208\%20QIS4\%20Report\%20Table\%20Annex.pdf, accessed 10 March 2010.

CEIOPS (2009) 'CEIOPS' Advice for Level 2 Implementing Measures on Solvency II: Supervisory Reporting and Public Disclosure Requirements, from https://eiopa.europa.eu/fileadmin/tx_dam/files/consultations/ consultationpapers/CP58/CEIOPS-L2-Final-Advice-Supervisory-Reporting-and-Disclosure.pdf, accessed 10 March 2010.

CRO Forum (2008) Public risk Disclosure under Solvency II - Principles, Content Outline and Sample Report, from http://www.croforum.org/assets/files/publications/publicriskdisclosure-croforumproposal2008-11-11_ draft_croformat_v2.pdf, accessed 2 October 2009.

De Mey, J. (2009) 'Reporting on the financial performance of life insurers', The Geneva Papers on Risk and Insurance - Issues and Practice 34(2): 228-241.

Deumes, R. (2008) 'Corporate risk reporting - A content analysis of narrative risk disclosures in prospectuses', Journal of Business Communication 45(2): 120-157.

Deumes, R. and Knechel, W.R. (2008) 'Economic incentives for voluntary reporting on internal risk management and control systems', Auditing: A Journal of Practice \& Theory 27: 35-66.

Dia, M. and Zéghal, D. (2008) 'Fuzzy evaluation of risk management profiles disclosed in corporate annual reports', Canadian Journal of Administrative Sciences 25(3): 237-254.

Eling, M. (2010) What do we know about market discipline in insurance? Working Paper, University of Ulm.

Eling, M. and Schmeiser, H. (2010) 'Insurance and the credit crisis: Impact and ten consequences for risk management and supervision', The Geneva Papers on Risk and Insurance-Issues and Practice 35(1): 9-34.

Finch, N. (2010) 'Towards an understanding of cultural influence on the international practice of accounting', Journal of International Business and Cultural Studies 2(1): 1-6. 
Gray, S.J. (1988) 'Towards a theory of cultural influence on the development of accounting systems internationally', ABACUS 24(1): 1-15.

Hassan, M.K. (2009) 'UAE corporations-specific characteristics and level of risk disclosure', Managerial Auditing Journal 24(7): 668-687.

Helbok, G. and Wagner, C. (2006) 'Determinants of operational risk reporting in the banking industry', Journal of Risk 9(1): 49-74.

Hirtle, B. (2007) Public Disclosure, Risk, and Performance at Bank Holding Companies, Federal Reserve Bank of New York Staff Report, 293.

Hofstede, G. (1980) Culture's Consequences: International Differences in Work-related Values, London: Sage Publications.

IAIS (2002) 'Guidance paper on public risk disclosure by insurers', from http://www.iaisweb.org/_temp/ Guidance_paper_on_public_disclosure_by_insurers.pdf, accessed 2 October 2009.

IAIS (2004) 'Standard on disclosures concerning technical performance and risks for non-life insurers and reinsurers', from http://www.iaisweb.org/_temp/Standard_on_disclosure_concerning_technical_performance_ and_risks_for_non_life_insurers_and_reinsurers.pdf, accessed 2 October 2009.

IAIS (2005) 'Standard on disclosures concerning investment risks and performance for insurers and reinsurers', from http://www.iaisweb.org/_temp/Disclosures_concerning_investment_risks_and_performance_ for_insurers_and_reinsurers.pdf, accessed 2 October 2009.

IAIS (2006) 'Standard on disclosures concerning technical risks and performance for life insurers', from http://www.iaisweb.org/_temp/Disclosures_concerning_technical_risks_and_performance_for_life_ insurers.pdf, accessed 2 October 2009.

IAIS (2008) 'Survey on implementation of IAIS disclosure standards', from http://www.iaisweb.org/_temp/ Survey_on_implementation_of_IAIS_Disclosure_standards_-_Report_on_responses_December_2008.pdf, accessed 30 September 2009.

Jensen, M.C. and Meckling, W.H. (1976) 'Theory of the firm: Managerial behavior, agency costs and ownership structure', Journal of Financial Economics 3(4): 305-360.

Joint Forum (2004) 'Financial disclosure in the banking, insurance and securities sectors: Issues and analysis', BIS. from http://www.bis.org/publ/joint08.pdf, accessed 2 October 2009.

Kajüter, P. and Winkler, C. (2003) 'Die Risikoberichterstattung der DAX100- Unternehmen im Zeitvergleich' ["Risk reporting of the DAX100 companies: A chronological comparison"]', Kapitalmarktorientierte Rechnungslegung 5: 217-228.

Konishi, N. and Ali, M. (2007) 'Risk reporting of Japanese companies and its association with corporate characteristics', International Journal of Accounting, Auditing and Performance Evaluation 4(3): $263-285$

KPMG (2008) 'Financial institutions risk disclosure-Best practice survey 2008', from http://www.kpmg .com/DK/da/nyheder-og-indsigt/nyhedsbreve-og-publikationer/publikationer/brancher/financialservices/ Documents/KPMG\%20Financial\%20Institution\%20Risk\%20Disclosure\%20Best\%20Practice\% $\%$ Survey\% 202008.pdf, accessed 21 September 2009.

Kraft, M. and Nolte, A. (2005) 'Risikoberichterstattung von Versicherungs- unternehmen-Analyze der Risikoberichte im Zeitablauf' ["Insurance company risk reporting-Analysis of risk reporting over time"]', Zeitschrift für die gesamte Versicherungswissenschaft 94: 423-455.

Krippendorff, K. (2004) Content Analysis-An Introduction to its Methodology, 2nd ed., Thousand Oaks, CA: Sage Publications.

Lajili, K. and Zéghal, D. (2005) 'A content analysis of risk management disclosures in Canadian annual reports', Canadian Journal of Administrative Sciences 22(2): 125-142.

Lang, M.H. and Lundholm, R.J. (1996) 'Corporate disclosure policy and analyst behavior', The Accounting Review 71(4): 467-492.

Li, F. (2006) Do stock markets investors understand the risk sentiment of corporate annual reports? Working Paper, University of Michigan at Ann Arbor-Stephen M. Ross School of Business.

Linsley, P.M. and Lawrence, M.J. (2007) 'Risk reporting by the largest UK companies: Readability and lack of obfuscation', Accounting, Auditing \& Accountability Journal 20(4): 620-627.

Linsley, P.M. and Shrives, P.J. (2005a) 'Transparency and the disclosure of risk information in the banking sector', Journal of Financial Regulation and Compliance 13(3): 205-214.

Linsley, P.M. and Shrives, P.J. (2005b) 'Examining risk reporting in UK public companies', Journal of Risk Finance 6(4): 292-305. 
Linsley, P.M. and Shrives, P.J. (2006) 'Risk reporting: A study of risk disclosures in the annual reports of UK companies', British Accounting Review 38(4): 387-404.

Linsley, P.M., Shrives, P.J. and Crumpton, M. (2006) 'Risk disclosure: An exploratory study of UK and Canadian banks', Journal of Banking Regulation 7(3-4): 268-282.

Lopes, P.T. and Rodrigues, L.L. (2007) 'Accounting for financial instruments: An analysis of the determinants of disclosure in the Portuguese stock exchange', International Journal of Accounting 42(1): 25-56.

Marston, C.L. and Shrives, P.J. (1991) 'The use of disclosure indices in accounting research: A review article', British Accounting Review 23(3): 195-210.

McMahon, L. (2009) 'Insurers call for more guidance on Solvency II', Insurance Age, 17 December.

Morgan, D.P. (2002) 'Rating banks: Risk and uncertainty in an opaque industry', American Economic Review 92(4): 874-888.

Nier, E. and Baumann, U. (2006) 'Market discipline, disclosure and moral hazard in banking', Journal of Financial Intermediation 15(3): 332-361.

O'Brien, R.M. (2007) 'A caution regarding rules of thumb for variance inflation factors', Journal of Quality and Quantity 41(5): 673-690.

Pérignon, C. and Smith, D.R. (2008) 'The level and quality of Value-at-Risk disclosure by commercial banks', Journal of Banking and Finance 34(2): 362-377.

PricewaterhouseCoopers (2008) 'Does ERM matter? Enterprise risk management in the insurance industry', from http://www.pwc.com/gx/en/insurance/pdf/erm_survey.pdf, accessed 18 December 2009.

Robb, S.W.G., Single, L.E. and Zarzeski, M.T. (2001) 'Nonfinancial disclosures across Anglo-American countries', Journal of International Accounting, Auditing \& Taxation 10(1): 71-83.

Sandt, C. and Schmitt, T. (2010) Versicherer scheuen Vergleiche [Insurers shy away from comparisons], Handelsblatt, 8 February.

Schanz, K.-U. (2009) 'Maintaining stakeholder trust in difficult times: Some fundamental reflections in light of the credit crisis', The Geneva Papers on Risk and Insurance - Issues and Practice 34(2): 260-270.

Schrand, C.M. and Elliott, J.A. (1998) 'Risk and financial reporting: A summary of the discussion at the 1997 AAA/FASB conference', Accounting Horizons 12: 271-282.

Solomon, J.F., Solomon, A., Norton, S.D. and Joseph, N.L. (2000) 'A conceptual framework for corporate risk disclosure emerging from the agenda for the corporate governance reform', British Accounting Review 32(4): 447-478.

Sundmacher, M. (2006) Consistency of risk reporting in financial services firms, Working Paper, University of Western Sydney.

Vandemaele, S., Vergauwen, P. and Michiels, A. (2009) Management risk reporting practices and their determinants, Working Paper, Hasselt University.

Vanstraelen, A., Zarzeski, M.T. and Robb, S.W.G. (2003) 'Corporate non-financial disclosure practices and financial analyst forecast ability across three European countries', Journal of International Financial Management and Accounting 14: 249-278.

Watts, R.L. and Zimmerman, J.L. (1990) 'Positive accounting theory: A ten year perspective', Accounting Review 65(1): 131-156.

Wissmann, M., Toutenburg, H. and Shalabh (2007) Role of Categorical Variables in Multicollinearity in Linear Regression Model, Technical Report, 8, Ludwig- Maximilians-Universität Munich.

Woods, M., Dowd, K. and Humphrey, C. (2008) 'Market risk reporting by the world's top banks: Evidence on the diversity of reporting practice and the implications for international accounting harmonization', RC-SAR 11: 9-42.

\section{About the Authors}

Dirk Höring studied business administration at the Humboldt University of Berlin and the University of Virginia. Between 2007 and 2009 he worked for the Risk Management Practice of McKinsey \& Company, Inc. In 2009 he started his doctoral studies at the Dr. Wolfgang Schieren Chair of Insurance and Risk Management at the Humboldt University of Berlin. His research interests include risk disclosures and organisation of risk management. 
Helmut Gründl holds the Chair of Insurance and Regulation at the Goethe University in Frankfurt am Main and is Managing Director of the International Center for Insurance Regulation (ICIR) sponsored by the German Insurance Association (GDV) and the State of Hesse. Between 1999 and 2010 he held the Chair for Insurance and Risk Management at Humboldt University of Berlin. His research interests cover all aspects of insurance regulation, risk management, insurance pricing and capital allocation. 